\title{
Capital e Colonização: A Constituição da Periferia do Sistema Capitalista Mundial ${ }^{\star}$
}

\author{
- RODRIgo AlVES TEIXEIRA*
}

\begin{abstract}
RESUMO
Este artigo tem dois objetivos. Em primeiro lugar, discutir as linhas principais da historiografia sobre o período colonial brasileiro, da perspectiva dos seus fundamentos metodológicos. Esta análise crítica da historiografia parte de uma leitura de Marx que resgata a herança da dialética hegeliana na compreensão da concepção marxiana da História. Em segundo lugar, a partir da defesa de um dos modelos propostos no debate, baseado na categoria capital escravista-mercantil como uma particular forma do capital que existiu no período colonial, busca-se avançar na compreensão deste período argumentando que ele faz parte de um processo histórico de consolidação do capitalismo enquanto um sistema mundial, processo esse que tem o capital como um sujeito automático. Defendemos que a força da forma capital prescinde da generalização das relações burguesas "típicas" para todo o globo, e que o sistema colonial não deve ser interpretado como um outro modo de produção, nem como sendo apenas uma peça da engrenagem da acumulação primitiva de capital. O "sentido da colonização" é, portanto, a constituição da periferia de um sistema capitalista mundial.
\end{abstract}

Palavras-CHave

sentido da colonização, historiografia, metodologia, dialética, capitalismo

\section{ABSTRACT}

This paper has two aims. First, to discuss the main theoretical approaches about the Brazilian colonial period, from the perspective of their methodological foundations. This critical analysis of the historiography is based on an interpretation of Marx that recovers the influence of Hegelian dialectic in Marxian view of History. Second, from the defense of one of those models present on the debate, based on the concept of "capital escravista-mercantil" as a particular form of capital which existed during the colonial period, we try to advance on the comprehension of this period arguing that it is part of the historical process of consolidation of the capitalism as a world system, process this which has the capital as an automatic subject. We defend that the force of the capital form doesn't need the generalization of the typical bourgeois relations for the entire globe, and that the colonial system neither should be understood as another mode of production, nor as a mere piece of the primitive accumulation of capital. The "sentido da colonização" is, therefore, the constitution of the periphery of the world capitalist system.

\section{KEY WORDS}

sentido da colonização, historiography, methodology, dialectic capitalism

\section{JEL ClassificATION \\ NOI, N76}

+ Uma primeira versão do presente texto foi apresentada no encontro da ANPEC de 2005, em Natal-RN. Naquela versão, nos ativemos às questões metodológicas. Aqui, aprofundamos aquelas discussões em alguns pontos, em particular na apresentação da concepção dialética das significações - para o que nos apoiamos em Fausto (1987 e 1988) e suas implicações para a leitura da concepção marxiana da História. Além da discussão metodológica, acrescentamos uma discussão sobre o desenvolvimento do capitalismo enquanto um sistema mundial e sobre o lugar da colonização nesse processo, para embasar a crítica ao uso das categorias modo de produção e formação econômico-social na interpretação de nosso período colonial. Este artigo foi desenvolvido a partir das discussões suscitadas na disciplina "Formação Econômica e Social do Brasil: Modelos Interpretativos", ministrada no Instituto de Pesquisas Econômicas da USP pelo professor Nelson Nozoe no primeiro semestre de 2003, disciplina esta que foi concebida no bojo do N.E.H.D (Núcleo de Estudos em História Demográfica da FEA/USP). Agradeço aos demais colegas do curso pelas excelentes e instigantes discussões e aos professores Nelson Nozoe, José Flávio Motta e Iraci Costa, com os quais tive a oportunidade de discutir uma versão preliminar deste texto. Agradeço também as sugestões e críticas de um parecerista anônimo desta revista. Os erros e imprecisões que aqui permanecerem são de minha responsabilidade.

* Professor do Departamento de Economia da FEA-USP e Analista do Banco Central do Brasil. E-mail: rodteix@usp.br Endereço para correspondência. Av. Prof. Luciano Gualberto, 908, FEA-2, sala 239, Cidade Universitária, São Paulo-SP, CEP 05508-900.

(Recebido em novembro de 2004. Aceito para publicação em março de 2006). 


\section{INTRODUÇÃO}

O modelo interpretativo proposto por Caio Prado Jr. em sua obra Formação do Brasil contemporâneo exerce forte influência até hoje na historiografia sobre o período colonial brasileiro. Sua influência se exerce tanto naqueles que procuram manter a idéia do "sentido da colonização", vendo a colônia como uma sociedade cuja estrutura e funcionamento foram determinados pelo comércio externo e, portanto, como um mero empreendimento a serviço do capital comercial europeu, quanto naqueles que, buscando criticar tal visão e defendendo uma autonomia da dinâmica interna à colônia, vêem-se obrigados a discutir o modelo pradiano e seus desenvolvimentos posteriores, usando-o como ponto de partida das suas críticas.

O objetivo do presente trabalho é discutir as linhas principais da historiografia sobre o período colonial brasileiro que surgiram a partir do modelo pradiano e, a partir da análise dos seus fundamentos metodológicos, fazer uma avaliação do poder explicativo e adequação dos modelos propostos.

Nesta historiografia, sabe-se que a maioria dos autores buscou analisar a realidade colonial brasileira com base nos conceitos desenvolvidos por Marx, ou seja, na linha do Materialismo Histórico, e Caio Prado Jr. foi pioneiro na aplicação do materialismo histórico à realidade brasileira. Entretanto, apesar de aparentemente partirem de uma mesma concepção teórica, tais autores chegam a resultados muito diferentes. Tais diferenças, como buscaremos defender neste trabalho, decorrem principalmente das diferentes leituras da obra de Marx, e são de fundo metodológico. Desta forma, torna-se necessário compreender as diferentes leituras de Marx que foram feitas pelos autores do debate, explicitando os aspectos metodológicos dessas leituras.

Partindo dos estudos desenvolvidos em outro trabalho (Teixeira, 2003), ${ }^{1}$ daremos destaque à tensão existente entre três visões da teoria do conhecimento em ciências sociais: o positivismo (e também o estruturalismo), com a sua busca de relações invariantes, de validade universal no espaço e no tempo; o historicismo, com a defesa de que cada arranjo social é uma particularidade histórica e que os conceitos não podem ser generalizados para o estudo de distintos arranjos sociais, o que aponta para os

l O trabalho citado, que é minha dissertação de mestrado, teve o objetivo de estudar como as três grandes visões da teoria do conhecimento (o positivismo, o historicismo e a dialética) influenciaram os debates metodológicos na ciência econômica, centrando a discussão na forma como cada uma delas vê as relações entre sujeito e objeto, a possibilidade da objetividade do conhecimento científico e a adequação da teoria ao objeto. As análises que faço aqui sobre essas três visões da teoria do conhecimento estão mais bem fundamentadas nesse trabalho, para o qual encontrei grande apoio e influência na obra de Michael Löwy (Löwy, 1996). Entretanto, percorri um caminho um tanto diferente de Löwy, que destaca a dimensão das relações sujeito-objeto pela via da sociologia do conhecimento, enquanto preferi destacar a dimensão da historicidade dos conceitos no plano da possibilidade objetiva em geral de seu surgimento, e não da possibilidade subjetiva de surgir a partir de determinada visão de mundo ou da maior ou menor objetividade que se pode alcançar a partir das diferentes visões de mundo. 
limites do conhecimento; e a dialética, que com uma mudança de registro lógico, ou seja, com o rompimento com os limites da lógica formal, busca trabalhar a contradição entre a generalidade e a particularidade dos conceitos.

As discussões nas quais nos centraremos são basicamente as seguintes, que consideramos serem as mais importantes nas críticas ao modelo pradiano:

1) a acusação, imputada ao modelo pradiano, de que a idéia de "sentido" seria teleológica;

2) as críticas segundo as quais o escravismo (e não o capital comercial), que não é elemento central na obra de Caio Prado (chegando mesmo, em Fernando Novais, a ser visto como resultado do tráfico, ou seja, explicado pelo capital comercial), deveria ser a categoria central no estudo da Colônia, pois seria seu traço definidor e diferenciador;

3) o uso da categoria Modo de Produção para estudar o Brasil-Colônia, no bojo das críticas de que o modelo pradiano seria circulacionista, ou seja, centrado na circulação comercial, e não nas relações de produção, e por isto não seria rigoroso na aplicação do materialismo histórico à realidade brasileira;

4) as críticas à excessiva ênfase dada à dependência e subordinação da economia e da estrutura da sociedade colonial ao mercado externo. Embora esta crítica esteja ligada às anteriores, ela se desenvolveu não apenas no plano teórico, mas principalmente baseada nos desenvolvimentos da pesquisa empírica a partir da década de 1970 (particularmente com a demografia histórica), que apontaram uma complexidade na economia colonial que não podia ser explicada apenas pela idéia do "sentido".

Este trabalho se divide em 5 seções, além desta introdução. Na seção 1 apresentaremos o modelo proposto por Caio Prado Jr. em sua obra Formação do Brasil contemporáneo. A seção 2 é dedicada aos desenvolvimentos teóricos que vão ao encontro deste modelo, como as obras de Celso Furtado e Fernando Novais. Na seção 3, apresentamos as discussões teóricas a respeito do modelo pradiano, com as críticas e modelos alternativos que surgiram, particularmente as propostas de Antônio Barros de Castro, Ciro Flamarion Cardoso e Jacob Gorender, entre os anos 1970 e 1980. Na quarta seção apresentaremos dois modelos recentes, da década de 1990, que buscam superar as dificuldades que permaneceram nos modelos apresentados na seção 2. A primeira é a proposta de João Luís Fragoso e Manolo Florentino, que se centram no conceito de formação econômico-social para tentar superar os limites da categoria modo de produção, e destacam de maneira mais radical a autonomia da dinâmica interna da colônia. A segunda é a proposta de Iraci Costa e Julio Pires, que busca conciliar a noção 
de dependência e relativa falta de autonomia da colônia com as evidências empíricas obtidas da demografia histórica que mostraram os limites da noção de "sentido" para explicar a complexidade da sociedade colonial.

Finalmente, na última seção, faremos as considerações finais e apresentaremos nossa conclusão.

\section{O "SENTIDO DA COLONIZAÇÃOO DE CAIO PRADO JR.}

O objetivo desta seção é apresentar as características principais do modelo interpretativo de Caio Prado Jr. Logo no início de sua obra, ao tratar do "Sentido da Colonização", o autor explicita sua posição metodológica, que se assemelha muito à postura metodológica de Marx. Emparelhemos as duas citações para ficar clara a comparação:

"Todo povo tem na sua evolução, vista à distância, um certo 'sentido'. Este se percebe não nos pormenores da sua história, mas no conjunto dos fatos e acontecimentos essenciais que a constituem num longo periodo de tempo. (...) Visto deste ângulo geral e amplo, a evolução de um povo se torna explicável. Os pormenores e incidentes mais ou menos complexos que constituem a trama de sua história e que ameaçam por vezes nublar o que verdadeiramente forma a linha mestra que a define, passam para o segundo plano, e só então nos é dado alcançar o sentido daquela evolução, compreendê-la, explicá-la. (...) Não se compreende por isso, se desprezarmos inteiramente aquela evolução, o que nela houve de fundamental e permanente. Numa palavra, o seu sentido.” (Prado Jr., 1981, p. 13-14, grifo do autor).

"A sociedade burguesa é a organização histórica mais desenvolvida, mais diferenciada, da produção. As categorias que exprimem suas relações, a compreensão de sua própria articulação, permitem penetrar na articulação e nas relações de produção de todas as formas de sociedade desaparecidas, sobre cujas ruinas e elementos se acha edificada, e cujos vestigios, não ultrapassados ainda, leva de arrastão desenvolvendo tudo que fora antes apenas indicado que toma assim toda a sua significação, etc. A anatomia do homem é a chave da anatomia do macaco. O que nas espécies animais inferiores indica uma forma superior não pode, ao contrário, ser compreendido senão quando se conbece a forma superior." (Marx, 1978, p. 120). 
Em primeiro lugar, há que se ressaltar que os objetivos de Caio Prado e Marx são diferentes. Enquanto este último fala da passagem de um modo de produção a outro, Caio Prado não destaca rupturas deste nível, e nem utiliza em sua obra o conceito de modo de produção, ao menos não explicitamente. O que há em comum nas duas citações é a relação entre passado e presente, a idéia de que, ao se conhecer o resultado do desenrolar da história, é possível então, a partir do conhecimento do presente, olhar para trás para identificar quais as relações mais importantes para se compreender a dinâmica das sociedades passadas que a distanciavam ou que a desenvolveram na sociedade presente. É o presente que fornece a chave para o passado, ou seja, é o conhecimento do presente que permite identificar quais os elementos essenciais para se compreender o passado, separando estes elementos essenciais do que é secundário ou apenas acessório, ou seja, dos "pormenores de sua história".

Tanto em Marx como em Caio Prado Jr. nota-se então a idéia de um "sentido" na história, mas este sentido não é teleológico (como em Hegel), ou seja, não é um sentido que existe a priori, determinístico, cujo télos é previamente conhecido, mas um sentido que é conhecido, ou melhor dizendo, um sentido que é reconstruído racionalmente apenas a posteriori, ou seja, a partir do conhecimento da sociedade que resultou do desenrolar histórico.

Na sua famosa comparação, Marx diz que é a partir da anatomia do homem que se conhece a anatomia do macaco, ou seja, que é a partir da forma mais desenvolvida que se pode construir categorias e perceber determinações que apareciam atrofiadas ou apenas em forma embrionária na forma menos desenvolvida. Esse olhar da forma menos desenvolvida é feita a partir do conhecimento da forma mais desenvolvida, o que não implica, entretanto, que do "macaco" - de um antropóide - deveria emergir o homem como necessidade lógica, e portanto nada garante que o futuro estava inscrito como necessidade lógica no passado, de forma que a história se processaria como a realização de uma racionalidade metafísica. ${ }^{3} \mathrm{O}$ espaço da contingência existe e é claro

2 Ao falar de pormenores aqui, nos parece que Caio Prado Jr. esteja falando dos acontecimentos empíricos isolados, ou seja, da história factual. No caso da nossa história colonial são, por exemplo, os sucessivos "ciclos" de produtos de exportação, descritos por Roberto Simonsen, fenômenos isolados aos quais Caio Prado Jr busca dar uma significação teórica, ou seja, encontrar a essência que os move. Também podem ser vistos como pormenores os elementos presentes na sociedade colonial que não estavam diretamente relacionados ao sentido da colonização, mas eram subsidiários a ele, como o mercado interno da colônia e seus elementos constituintes. Fazendo parte da "geração de 30", ao lado de Sérgio Buarque de Hollanda e Gilberto Freyre (como destaca Antônio Cândido no seu prefácio ao Raizes do Brasil, de Sérgio Buarque de Hollanda), Caio Prado participa assim da revolução de nossa historiografia que busca romper com a história factual para engajar-se na formulação de teorias, ou seja, de modelos interpretativos que buscam explicar os fatos isolados em seu conjunto, identificando a lógica que os une.

3 Marx alerta para este erro de considerar a história de forma teleológica, como uma sucessão de etapas predeterminadas, na passagem seguinte: "O chamado desenvolvimento histórico repousa em geral sobre o fato de a uiltima forma considerar as formas passadas como etapas que levam a seu próprio gran de desenvolvimento, e dado que ela raramente é capaz de fazer a sua própria crítica, e isso em condições bem determinadas - concebe-as sempre sob um aspecto unilateral.” (Marx, 1978, p. 120). Além do risco de teleologia, Marx 
em Marx, embora não tenha ficado claro para uma certa vulgarização nas teses do marxismo ortodoxo. Claro que, no caso da evolução das espécies na biologia, a contingência é algo natural (embora a intervenção humana na natureza tenha mudado isso profundamente desde que Darwin divulgou suas idéias), ao passo que no campo social a realização de estados possíveis depende dos conflitos entre classes e grupos sociais, ou seja, se dá no plano da política.

Dessa forma, assim como não é correto tratar a "sucessão dos modos de produção", em Marx, como um processo evolutivo histórico-natural, e mais ainda, com uma ordem de evolução predefinida, também não é correta, a nosso ver, a acusação de que a idéia de "sentido da colonização" proposta por Caio Prado seja teleológica: a lógica do "sentido" não existe a priori, como necessidade lógica, mas é reconstruída a posteriori pelo sujeito do conhecimento, como contingência que se realizou efetivamente, e a partir da qual é possível olhar para o passado e perceber lá os elementos que o desenvolveram na forma presente.

Caio Prado também confere outra significação à palavra "sentido", o que já é um salto da metateoria para a teoria: ao ver na colônia um organismo econômico primordialmente voltado ao fornecimento de produtos tropicais e de metais preciosos para o mercado europeu, destaca então este "sentido" da produção colonial, ou seja, seu direcionamento para o mercado externo, que conduzirá toda a obra da colonização e a sociedade colonial.

Assim, depois de explicitada a postura metodológica, o autor passa a estudar a Vida Material da colônia. Identificado este "sentido", percebido exatamente pela sua permanência e pelos seus efeitos sobre o presente (e este presente é o de um Brasil já independente politicamente nas primeiras décadas do século XX, mas que continuava dependente economicamente do mercado europeu), Caio Prado Jr. vai destacar os elementos essenciais da vida material da colônia, que serão a grande lavoura, a monocultura e o trabalho escravo, elementos estes que delinearam os contornos econômicos, sociais e geográficos da sociedade colonial que permaneceram até o presente. Após identificar estes elementos essenciais, ele busca separá-los do que é apenas acessório, dos elementos e acontecimentos secundários, entre os quais estarão o mercado interno e a produção voltada para ele, como a pecuária, o setor de serviços e a produção de gêneros alimentícios e utensílios para consumo interno.

aponta também para outro problema, presente nos economistas políticos, de partirem dos conceitos da sociedade capitalista e ignorarem as diferenças com relação às demais sociedades passadas, ou seja, ignorar a história: "Se é certo, portanto, que as categorias da Economia burguesa possuem [caráter de - RAT] verdade para todas as demais formas de sociedade, não se deve tomar isto senão cum grano salis [ou seja, em sentido bem determinado, com cautela - RAT]. Podem ser desenvolvidas, atrofiadas, caricaturadas, mas sempre essencialmente distintas." (op. cit). Muitos marxistas, porém, entre eles o estruturalismo de Althusser e o próprio Jacob Gorender (que discutiremos adiante), incorreram neste erro e tomaram as categorias criadas para o estudo da sociedade capitalista para estudar as sociedades passadas sem muita cautela. 
Busca mostrar, então, que os elementos secundários estão totalmente subordinados aos elementos essenciais: a produção para o mercado interno surge apenas como atividade subsidiária da grande lavoura escravista exportadora e tem sua dinâmica determinada pela dinâmica do mercado externo, ou seja, pela dinâmica dos preços internacionais e da demanda de gêneros agrícolas tropicais pela Europa. O capital comercial é então elemento central para a compreensão da sociedade colonial e da sua dinâmica.

Finalmente, a partir do estudo da Vida Material, dentro da postura do materialismo histórico, nos capítulos finais da obra o autor passa então a analisar a Vida Social da colônia, ou seja, passa a estudar a superestrutura que se formou sobre aquela base. Aqui fica clara sua filiação ao materialismo histórico: a vida social é explicada a partir da vida material. ${ }^{4}$

Assim, no modelo pradiano, a economia e a sociedade coloniais seriam um mero apêndice de um sistema mais amplo que tem seu centro na Europa, e toda sua dinâmica se subordinaria àquele centro. Não havia aqui espaço para a reprodução de uma sociedade autônoma.

Na próxima seção trataremos de dois outros autores que são vistos pela historiografia crítica como desenvolvimentos do modelo pradiano. O primeiro é Celso Furtado (Furtado, 1959), que desenvolveu a idéia de subordinação da colônia ao comércio externo, buscando explicitar os ciclos reflexos da economia colonial ao mercado europeu. Este autor, entretanto, desenvolve suas idéias a partir de uma perspectiva keynesiana, e não marxista, e não colocou sua obra explicitamente como um aperfeiçoamento do modelo de Caio Prado Jr. São dois os motivos para, apesar disso, destacarmos aqui sua obra: sua importância na historiografia e na interpretação da economia brasileira e latino-americana, e pelo fato de Fragoso e Florentino, em seu Arcaísmo como projeto - obra que discutiremos adiante nesse trabalho - colocarem Furtado ao lado de Caio Prado Jr. e Fernando Novais como fazendo parte de um mesmo modelo interpretativo,

4 Não poderíamos omitir algumas opiniões sobre este complicado tema. De nossa parte, não acreditamos haver a separação radical entre base econômica e superestrutura, que a nosso ver foi utilizada por Marx muito mais para fins didáticos, embora tenha trazido mais problemas que soluçôes, o que ele próprio percebeu logo de início, tendo suprimido da sua obra $O$ capital o prefácio anterior (de 1857) que havia preparado (conhecido como o Prefácio à Contribuição à Crítica da Economia Política) e no qual apresentava tais noçôes. A dificuldade que levou Marx a suprimir tal prefácio é exatamente a dificuldade de se apresentar de antemão, antes do desenvolvimento lógico das categorias, conceitos construídos dialeticamente, que num prefácio aparecem como se fossem meras definições formais ou categorias abstratas, à maneira das teorias construídas com a lógica formal. Ou seja, trata-se de um problema em geral de se fazer prefácios quando se trata de uma obra construída com uma abordagem dialética, problema que já havia sido destacado por Hegel, no prefácio à sua Fenomenologia do espírito. Em Fausto (1988, especialmente cap. 4) encontramos uma exposição de como não é adequado separar a "base econômica" e a "superestrutura", pois a relação entre elas é uma relação dialética de posição e pressuposição. Infelizmente, como se sabe, as fáceis leituras vulgares de Marx tiveram preponderância sobre a leitura dialética, apesar das inúmeras advertências do próprio autor. Remetemos o leitor ao texto de Ruy Fausto, que desenvolve uma compreensão dialética da relação entre a "superestrutura" e a "base econômica". 
tendo em comum o fato de destacarem a ausência de dinâmica própria da economia colonial. O segundo é o próprio Fernando Novais (Novais, 1979), de orientação marxista e buscando desenvolver explicitamente o modelo pradiano, por meio da idéia do "sentido profundo da colonização", dando particular atenção ao papel do regime colonial na acumulação primitiva de capital na Europa. Veremos esses dois autores na próxima seção.

\section{O DESENVOLVIMENTO DO MODELO PRADIANO: CELSO FURTADO E FERNANDO NOVAIS}

Em sua obra Formação econômica do Brasil, Celso Furtado, ainda que partindo de referencial teórico bastante distinto do de Caio Prado Jr., chega a uma visão do Brasil colônia e, mais ainda, do Brasil das primeiras décadas do século XX, bastante parecida com a visão deste autor.

Inspirado pelas idéias keynesianas, particularmente na sua versão latino-americana desenvolvida no interior da Comissão Econômica para a América Latina (CEPAL), Celso Furtado se concentra no estudo da economia agrário-exportadora para mostrar como esta orientação para o mercado externo baseada no trabalho escravo foi prejudicial e atrasou o desenvolvimento econômico brasileiro, porque: 1) a produção extensiva de gêneros agrícolas, possibilitada pela abundância de terras e pelo fornecimento de mão-de-obra escrava, limitou muito o progresso técnico; 2) o direcionamento para o mercado externo, associado à escassa renda monetária que só seria ampliada no século XIX com o surgimento do trabalho assalariado, limitavam o desenvolvimento de um mercado interno que traria uma dinâmica própria à economia colonial, por meio dos mecanismos multiplicadores da renda presentes nas economias de mercado. Além disso, esta estrutura econômica precária e instável no tempo e no espaço, baseada na monocultura para exportação, na grande propriedade rural e no trabalho escravo promoveu grande concentração da renda entre as classes sociais e também do ponto de vista regional, ficando a renda concentrada no litoral e principalmente nos estados do Sudeste e Sul, que se desenvolveram muito à frente dos estados do Norte, Nordeste e Centro-Oeste, trazendo assim fortes desigualdades sociais e regionais.

Assim como Caio Prado Jr., Furtado vê a Colônia como um sistema econômico dependente, sem autonomia:

“(...) sendo uma plantação de produtos tropicais, a Colônia estava integrada nas economias européias, das quais dependia. Não constituia, portanto, um sistema autônomo, sendo simples prolongamento de outros maiores." (Furtado, 1959, p. 95). 
Sua principal contribuição para o desenvolvimento da tese da subordinação da colônia ao mercado externo está no estudo das flutuações da economia colonial. Como esta não tinha funcionamento autônomo, seu ritmo seria determinado pelas flutuações do mercado internacional. Para Furtado, os períodos de alta do preço internacional dos gêneros agrícolas de exportação representam períodos de expansão econômica nas atividades da colônia voltadas ao mercado interno, como a pecuária e a produção agrícola para consumo interno. Isto porque a grande lavoura tinha alto coeficiente de exportação, e o seu crescimento implicava o aumento da demanda por produtos internos para abastecimento. Nos períodos de baixa do preço internacional, ocorreria o inverso: parte da mão-de-obra escrava da grande lavoura seria deslocada para a produção de subsistência. Desta forma, a produção interna poderia até aumentar, mas não o faria de forma mercantilizada: ficaria concentrada na produção de subsistência. Assim, o aumento da produção interna não era acompanhado por um crescimento da renda monetária e, portanto, não haveria uma mudança estrutural na dinâmica econômica da colônia - o que só passaria a ocorrer, para Furtado, com o surgimento do trabalho assalariado trazido pela imigração européia e se consolidaria na década de 1930, com o centro dinâmico da economia se deslocando da agricultura para exportação para a indústria voltada ao mercado interno.

Fernando Novais, com sua obra Portugal e Brasil na crise do antigo sistema colonial, busca explicitamente, dentro do quadro teórico do marxismo, aprofundar a tese do "sentido da colonização" de Caio Prado Jr. A partir do conceito de Antigo Sistema Colonial, ligado ao Antigo Regime que se caracterizava no campo político pelo absolutismo e no econômico pelas doutrinas mercantilistas, o autor insere o sistema colonial no quadro maior da acumulação primitiva de capital na Europa, que teve como um de seus pilares a extração do excedente colonial por meio do monopólio exercido pela metrópole no comércio com as colônias.

"O regime do comércio colonial - isto é, o exclusivo metropolitano no comércio colonial - constituiu-se, ao longo dos séculos XVI, XVII e XVIII, no mecanismo através do qual se processava a apropriação por parte dos mercadores das metrópoles, dos lucros excedentes gerados nas economias coloniais: assim, pois, o sistema colonial em funcionamento, configurava uma peça da acumulação primitiva de capitais nos quadros do desenvolvimento do capitalismo mercantil europeu." (Novais, op. cit, p. 92).

Assim, Novais vai além de Caio Prado Jr. quando chama de "sentido profundo da colonização" o fato de a transferência do excedente da colônia para a metrópole por meio do monopólio do comércio de gêneros tropicais ter servido à acumulação primitiva de capital que impulsionaria a Revolução Industrial no século XVIII. Isto ocorreu 
particularmente pela transferência deste excedente que era apropriado por Portugal, subordinado que era no cenário europeu, para a Inglaterra.

Tudo na colônia seria explicado então por este "sentido profundo", sendo, assim como em Caio Prado Jr, o capital comercial a chave para a compreensão do sistema colonial: tudo o mais que existe na colônia será subsidiário e seu mercado interno, segundo Novais, será necessariamente reduzidíssimo. (op. cit, p. 109).

Até mesmo a escravidão terá sua explicação pelo capital comercial e pela acumulação primitiva: para Novais, não é a instituição escravidão que explica o surgimento do tráfico negreiro, ao contrário, é o fato de o tráfico negreiro também contribuir para a acumulação primitiva de capital que explica o fato de se ter optado pela mão-de-obra escrava africana.

A respeito desta tese sobre a escravidão, cabe uma qualificação: aqui de fato soa teleológica a idéia de que é o tráfico negreiro que explica a escravidão devido à existência de um "sentido profundo da colonização", que seria a acumulação primitiva. Assim, Novais parece ir além de Caio Prado no uso que dá à palavra "sentido", de forma que às vezes se tem a impressão de que a acumulação primitiva de capital constituía um télos metafísico. Se não for isto, haveria então outra possibilidade: a de que haveria, senão uma razão histórica metafísica (que está mais para Hegel que para Marx), um Sujeito, à frente do processo de acumulação primitiva. Consideremos duas possibilidades: este Sujeito poderia ser o próprio homem, ou seja, um sujeito dotado de intencionalidade, ou ainda o capital (ou uma de suas formas), ou seja, um sujeito automático.

No primeiro caso, poder-se-ia considerar que a acumulação primitiva de capital era um objetivo deliberado dos comerciantes ou das elites européias, que por isto teriam escolhido o escravo africano como mão-de-obra para a lavoura. Entretanto, esta possibilidade soa absurda, afinal as elites teriam que conhecer previamente o resultado da história.

Caberia considerar, ainda, a possibilidade, mais plausível, de haver como sujeito do processo o próprio capital, e então os homens surgiriam apenas como personificaçóes de categorias econômicas, como suportes do capital. Entretanto, o capital dentro do esquema teórico de Marx só passa a existir efetivamente quando a sua forma capital industrial, com o trabalho assalariado, passa a ser dominante, o que só pode ocorrer logicamente depois da acumulação primitiva do capital. Desta forma, uma vez considerado o capital - enquanto forma apenas ( $\left.\mathrm{D}-\mathrm{M}-\mathrm{D}^{\prime}\right)$, embora sem conteúdo, isto é, sem o trabalho assalariado e a grande indústria que constituem em Marx seu fundamento social - como sujeito já antes do advento do capitalismo industrial, o 
argumento de Novais ganharia mais força contra as acusações de ser teleológico. Ou seja, nos parece que falta a Novais, para fugir das acusações de ser teleológico, apontar qual o sujeito deste processo que gera a acumulação primitiva de capital.

Entretanto, há que se ressalvar o uso impróprio que Fernando Novais faz do termo capitalismo quando lhe confere a adjetivação "capitalismo comercial". 5 Marx fala sem dúvida de "capital comercial" como uma das formas históricas do capital, assim como o capital usurário e o capital industrial. Entretanto, ele jamais se referiu a um "capitalismo comercial". Ao contrário, Marx ressalta que apenas o capital industrial é uma forma autônoma, vale dizer, apenas ele pode constituir-se como Sujeito - ou seja, repor as condições de sua própria reprodução - e assim dar base a um modo de produção próprio (o capitalismo) - enquanto o capital comercial e o usurário sempre existiram em outras formas de organização social, exatamente porque não são formas autônomas e, portanto, não podem constituir um modo de produção específico. Desta forma, coloca-se a questão lógico-teórica de se o capital comercial pode ser considerado o sujeito deste processo de acumulação primitiva de capital, questão que não é abordada por Novais, que como vimos trabalha com a categoria, a nosso ver problemática na perspectiva marxista, de capitalismo comercial. ${ }^{6}$

Poder-se-ia ainda tentar utilizar o mesmo argumento metodológico do "sentido", discutido na seção 1, para defender Novais. Assim, ele estaria vendo não um sentido teleológico, mas apenas vendo a posteriori um sentido que era contingente, mas se realizou efetivamente na história. Entretanto, aqui se coloca outra questão: em que medida a colonização e a extração do excedente colonial foram de fato condições necessárias para a acumulação primitiva de capital? Esta questão também suscitou várias discussões na historiografia, ao que nos parece inconclusivas.

E ainda que essa relação entre extração do excedente colonial e acumulação primitiva de capital pudesse ser bem estabelecida, há um outro problema, de ordem lógica, para usar esse argumento quando se trata de Fernando Novais. Ele próprio acaba impossibilitando essa interpretação com a tese sobre a adoção da mão-de-obra escrava negra, visto que coloca esta opção como tendo se dado em função da acumulação primitiva, ou seja, uma escolha feita em função de um resultado histórico, mas antes que ele fosse conhecido, antes que a contingência se efetivasse historicamente. Na sua tese sobre os motivos da adoção do escravo negro é onde ele mais abre flancos para as acusações de teleologia.

5 É importante ressaltar que Caio Prado Jr. foi mais cuidadoso que Fernando Novais, pois fala em capital comercial, mas não em "capitalismo comercial", evitando, cautelosamente, usar a categoria modo de produção ao tratar do período colonial. Para uma discussão mais detalhada sobre a categoria "capitalismo comercial", ver o texto de Horacio Ciafardini (1988).

6 Como veremos na seção 4 , um dos modelos interpretativos mais recentes consegue resolver essa questão com a criação de uma nova forma do capital, o capital escravista-mercantil. 
Assim, um aspecto interessante do ponto de vista metodológico é que, ao procurar aprofundar o modelo de Caio Prado Jr., Novais o faz ao custo de tornar o modelo mais falseável - para usar a terminologia de Karl Popper (1972) - e, portanto, mais frágil às críticas. Isto talvez explique por que muitos críticos do modelo pradiano muitas vezes discutam em bloco os dois autores e, sem muito cuidado, transpóem críticas a Novais como se pudessem ser imputadas a Caio Prado Jr.

Desta forma, a idéia de "sentido da colonização", de Caio Prado, como defendemos anteriormente, não nos parece ser teleológica, embora as idéias de Novais a partir da noção de "sentido profundo da colonização" sejam menos facilmente defensáveis sob este aspecto. De qualquer forma, a relação entre a colonização e o desenvolvimento do capitalismo, que entendemos ser o grande avanço de Fernando Novais, deve ser desenvolvida. Voltaremos a essa questão adiante.

\section{AS CRÍTICAS AO MODELO PRADIANO}

Apesar das diferenças entre os três autores tratados anteriormente, os críticos como Fragoso e Florentino (2001) os tratam como constituindo um mesmo modelo interpretativo. Assim, o modelo interpretativo de Caio Prado Jr. e os desenvolvimentos feitos por Celso Furtado e Fernando Novais são tratados como o que se pode chamar de desenvolvimentos de um mesmo paradigma, dentro da chamada ciência normal, de Thomas Kuhn (1995).

Este modelo teria então as seguintes características:

1) há dois tipos de produção: a principal, voltada para a exportação e realizada em grandes propriedades e com mão-de-obra escrava; a subsidiária, voltada para o abastecimento interno e que era feita ou em propriedades menores com predominância de trabalhadores livres ou dentro da grande lavoura de exportação, que buscava a auto-suficiência como produção para subsistência;

2) baixo nível de desenvolvimento das forças produtivas em virtude do uso extensivo dos recursos naturais e da mão-de-obra escrava;

3) como decorrência dos pontos anteriores, uma grande concentração da renda monetária na elite agrário-exportadora e um mercado interno reduzido, cuja dinâmica era dependente da dinâmica do comércio externo; 
4) o capital comercial é a categoria-chave para se compreender a estrutura e o funcionamento da sociedade colonial, caracterizada pela falta de autonomia e pela dependência desta com relação ao mercado europeu.

Adiantamos na introdução a este trabalho os tipos de críticas "teóricas" 7 a este modelo. A primeira, que já discutimos nas duas seções anteriores, é a acusação de que a idéia de "sentido da colonização" seria teleológica. Embora Fernando Novais pareça às vezes incorrer em afirmações que soam teleológicas, não cremos ser justa a extensão de tais críticas a Caio Prado Jr.

As duas outras críticas teóricas - a relacionada à defesa da importância central do escravismo e a referente ao uso da categoria modo de produção - apontaram para a tentativa de superação do modelo, ou seja, para a construção de novos modelos interpretativos, e serão o objeto desta seção.

Já quanto às críticas empíricas, elaboradas a partir de pesquisas empíricas baseadas em fontes documentais, particularmente com o desenvolvimento da demografia histórica, que indicaram um mercado interno amplo e alto grau de complexidade da economia colonial (não prevista pelo modelo pradiano e seus desenvolvimentos), são mais esparsas e monográficas. ${ }^{8}$ Elas funcionaram mais, dentro da perspectiva de Karl Popper,

7 Utilizo aqui uma separação, para fins didáticos, entre o que seriam as "críticas teóricas" e as "críticas empíricas". Entendo por críticas teóricas aquelas que foram motivadas por ou partiram de discussões no plano lógico e metodológico, ou seja, de discussões sobre a maneira como os autores incorporaram a leitura de Marx. E por críticas empíricas estamos entendendo principalmente os desenvolvimentos da pesquisa com fontes primárias que evidenciam os limites do modelo pradiano no que diz respeito à apreensão da complexidade da economia colonial, e que partem dos estudos das fontes documentais. Claro que tanto as críticas empíricas não deixam de ser teóricas, como tampouco as críticas teóricas deixaram de se fundamentar em evidências empíricas. Mas há distinções claras entre os dois tipos de crítica, de forma que achamos justificável a distinção que, ainda que imperfeita, será útil para nossos propósitos neste artigo. Agradeço a um parecerista anônimo da revista por ter apontado para a necessidade de desenvolver melhor essa distinção que não estava clara no texto original, e assumo a responsabilidade pela opção de mantê-la no texto.

8 Remetemos aqui à noção abrangente de demografia histórica tal como apresentada por Motta e Costa (1997). Segundo os autores: "As centenas de trabalhos produzidos na área tiveram, ademais, regra geral, um caráter nitidamente monográfico. Amiúde detiveram sua atenção em uma ou poucas localidades, variando amplamente em termos do intervalo temporal contemplado. (...) O valor inestimável desses 'transbordamentos' de natureza monográfica está na própria demanda que ora se coloca no sentido da sintese dos achados neles presentes. De fato, os estudos monográficos apontaram claramente muitas das insuficiências, quer da aproximação, ainda paradigmática, de Caio Prado Júnior, quer de autores que o sucederam, perfilhando com maior ou menor intensidade ou criticando com maior ou menor contundência o modelo pradiano, tais como Celso Furtado, Fernando Novais, Ciro Flamarion Cardoso e Jacob Gorender, dentre outros.” (p. 156). Assim, há atualmente uma forte concentração dos esforços dos historiadores nos estudos monográficos baseados em fontes documentais, o que tem gerado uma enorme riqueza nos estudos empíricos a respeito da sociedade colonial, mas por outro lado há uma escassez de trabalhos visando dar interpretaçôes mais gerais, em modelos interpretativos da nossa história, agora enriquecidos pelas novas descobertas empíricas. Esse passo é sem dúvida o mais importante, como reconhecem Motta e Costa, que escrevem que se torna necessário agora "preocupar-se com a integração dos resultados alcançados no decurso dos últimos lustros em modelos mais gerais, interpretativos de nosso evolver histórico. Ai está, assim entendemos, o mais rico filão que se abre ao futuro da demografia histórica brasileira.” (p. 156). 
como testes empíricos para falsear o modelo pradiano, ou então, na perspectiva de Thomas Kuhn, explicitando anomalias dentro do paradigma. Não resultaram, assim, em um novo modelo interpretativo (novo paradigma teórico) - até pelos próprios limites de uma lógica indutiva, o caráter desses trabalhos não tem poder de ir muito além da dimensão dos estudos de caso, como de resto ocorreu com a Escola Histórica Alemã de economia ${ }^{9}$ - mas incentivaram a busca de novas teorias e foram incorporadas pelos dois modelos que surgirão na década de 1990 buscando superar os limites do modelo pradiano. Por isto, não dedicaremos a elas um tratamento sistemático, bastando-nos aqui lembrar suas conclusões e traços gerais, bem como sua utilização pelos autores dos novos modelos.

Passemos a analisar então as duas principais críticas teóricas que surgiram entre as décadas de 1970 e 1980. Gorender (1985), em sua obra O escravismo colonial, propõe, seguindo uma idéia proposta por Ciro Flamarion Cardoso (Cardoso, 1975), aplicar a categoria Modo de Produção para interpretar o período colonial no Brasil e nas colônias americanas em geral. Com isto, pretende o autor ser mais rigoroso que Caio Prado Jr. quanto à aplicação do materialismo histórico ao estudo do Brasil-Colônia, propondo uma inversão metodológica no enfoque que ele chama de circulacionismo, ou seja, do centro no capital comercial e no comércio externo, para dar ênfase às relações de produção, que configuram um modo de produção.

Assim, Gorender destacará a dinâmica e a lógica internas à colônia, sua autonomia como um modo de produção distinto de todos os que já haviam surgido. A relação de produção nas colônias era o escravismo, sendo esta categoria, portanto, a chave para o estudo da colônia, e não mais o capital comercial.

Assim, seus esforços na referida obra se concentram em mostrar que houve, nas Américas, um novo modo de produção, que ele, assim como Ciro Cardoso, chama de

9 É interessante notar que entre os historiadores (como entre outros cientistas sociais) há os dois extremos, aqueles mais voltados à teoria, e que constroem estruturas teóricas que buscam dar conta de largos períodos históricos em interpretaçóes mais gerais no espaço e no tempo, e aqueles mais voltados à pesquisa empírica, segundo os quais os dados refutam qualquer teoria que pretenda ter caráter geral. Isto nos parece ser parte da eterna discussão iniciada entre o positivismo e o historicismo na teoria do conhecimento: o positivismo (em sua versão do Círculo de Viena), recorrendo à lógica dedutiva, otimista com relação ao poder de explicação das teorias, na busca de "leis gerais", e o historicismo, recorrendo ao empírico (e às vezes cedendo à tentação de uma "lógica" indutiva) e com o seu ceticismo quanto às abstrações e generalizações das teorias, com sua tendência a produzir estudos de casos e trabalhos monográficos (como ocorreu com a Escola Histórica Alemã de Economia, no séc. XIX). Nesta tensão, não podemos nos esquecer que há tentativas de superação, das quais as mais influentes são as de Max Weber (herdeiro da Escola Histórica Alemã que buscou conciliar as duas noções adotando uma postura neokantiana com a noção de tipos ideais) e a de Karl Marx (com a dialética materialista). Neste trabalho, discutiremos apenas a linhagem marxista, embora reconhecendo a importância de uma tradição weberiana de interpretação, inaugurada no estudo da sociedade brasileira com Raizes do Brasil de Sérgio Buarque de Hollanda. Como veremos, na historiografia brasileira, esta tensão também aparece, e as diferenças entre os autores muitas vezes está na solução (ou falta de solução) metodológica para esta questão, que é central neste trabalho. 
Modo de Produção Escravista Colonial. Sua argumentação é feita então para, no bojo das categorias da Economia Política, descobrir as "leis" que regulam este novo modo de produção. Não entraremos nos detalhes de sua extensa obra, apenas nos centraremos em alguns pontos que julgamos centrais e nas suas proposições metodológicas.

Ainda que existissem de fato certas determinações autônomas na economia colonial (o que levou alguns autores a questionar a ênfase que foi dada no modelo pradiano à extração do excedente colonial e à visão da colônia como mero apêndice de um sistema mais amplo com centro na Europa), o próprio Ciro Cardoso ressalta que o modo de produção colonial é dependente.

Os aspectos principais e imediatos desta dependência são: 1) a reprodução da força de trabalho - a mão-de-obra escrava africana - se dava fora do modo de produção e era-lhe, portanto, exterior; e 2) apesar de a produção da mais-valia se dar na colônia, a realização desta mais-valia ou, como chamou Marx, o "salto mortal da mercadoria" (a passagem $\mathrm{M}$ - D’) se dava no mercado Europeu, dependia deste e, portanto, também era dada fora do modo de produção.

Entretanto, e esta é uma das críticas feitas a Gorender, para Marx o conceito de modo de produção implica uma totalidade orgânica, autônoma e que se reproduz a si própria. Dessa forma, torna-se frágil a idéia da existência de um modo de produção "dependente", como sugere Ciro Cardoso, visto que o capital comercial parece ter grande influência neste modo de produção que não se reproduz sem ele, seja na reprodução da força de trabalho, seja na realização da mais-valia, etapas fundamentais da lógica de funcionamento do referido modo de produção.

Gorender tentou, em outro texto, responder a essa objeção. (Gorender, 1980). ${ }^{10}$ De início, ele reconhece a necessidade do mercado externo para o Modo de Produção Escravista Colonial, quando escreve, à página 56, que enquanto para o capitalismo " $a$ teoria marxista da reprodução ampliada do capital dispensa a vinculação necessária entre capitalismo e modos de produção não capitalistas”, para o modo de produção colonial, ao contrário, "tanto a reprodução ampliada como a reprodução simples não dispensam a realização da massa da produção mercantil no mercado externo, que deve ser um mercado não-escravista." Assim, continua o autor, se para o capitalismo "o mercado externo não constitui senão um prolongamento do mercado interno", e por isso, "do ponto de vista teórico, o mercado externo não precisa ser conceituado", quanto ao escravismo colonial, en-

10 Esse texto de Gorender é muito rico, e de grande importância para nossa discussão pelo seu caráter metodológico, inclusive porque o autor também discute o estruturalismo de Althusser (identificando sua noção kantiana de criação de conceitos como universais abstratos) e o historicismo, bem como se defronta com a teoria da dependência de Fernando Henrique Cardoso e Enzo Faletto (Cardoso e Faletto, 1975), e com um texto do filósofo José Arthur Gianotti (Gianotti, 1976). 
tretanto, "o mercado externo não-escravista constitui um pressuposto necessário do processo de produção.” (Grifos no original).

Apesar desse reconhecimento, Gorender insiste na idéia de que o modo de produção escravista colonial não deixa de ser uma totalidade orgânica. Escreve ele:

"Enquanto o modo de produção capitalista cria seu próprio tipo de circulação, que o integra internamente, o escravismo colonial se vincula a um tipo de circulação externa, que ele próprio não cria, mas se limita a adequar ao seu processo de produção. Com isto, o modo de produção escravista colonial não deixa de ser uma totalidade orgânica, conceitualmente definida como tal, sobretudo pela vigência de leis rigorosamente específicas.” (p. 57).

Assim, Gorender continua afirmando, apesar da ressalva, que "o modo de produção escravista colonial não deixa de ser uma totalidade orgânica", mas de forma alguma consegue arrolar argumentos suficientes para demonstrar essa afirmação ao longo do texto. Ainda que em sua obra sobre o Escravismo Colonial ele tenha buscado mostrar essas leis específicas do modo de produção escravista colonial, não nos parece de forma alguma suficiente dizer que pela existência de leis específicas ele pode ser considerado uma totalidade orgânica, ainda mais depois do próprio reconhecimento que o autor fez de que essa "totalidade orgânica” depende do mercado externo.

Na seção seguinte do referido texto, após expor sua posição sobre a "totalidade dependente" sem, no entanto, defendê-la satisfatoriamente, Gorender parte para a crítica às interpretações alternativas, que constituem aquilo que ele chama de "integracionismo", presente nas teorias da dependência e também em um texto de Giannotti (1976). Essa postura que ele chama de integracionista é a alternativa à idéia de se utilizar a categoria modo de produção para se compreender o período colonial. Uma das maneiras pelas quais se apresenta esse integracionismo é na visão que subordina a dinâmica do interno à dinâmica do externo, e Gorender situa aqui as teorias da dependência, e mesmo na sua vertente mais rigorosa, que segundo o próprio autor seria a de Cardoso e Faleto (1975).

Outra forma sob a qual aparece esse integracionismo (embora não incompatível com a primeira, senão mesmo complementar) é a visão que "acomoda sob a categoria de capitalismo as mais diversas realidades sócio-bistóricas” (p. 59), eliminando assim uma diferença essencial entre capitalismo e não-capitalismo, que estaria presente em Rosa 
Luxemburgo. ${ }^{11}$ A respeito desse segundo tipo de integracionismo, representado por Giannotti (1976), escreve Gorender:

"A explicação tem sido a de que, uma vez integrados no circuito da reprodução do capital, os modos de produção pré-capitalistas, que o capitalismo encontra ou mesmo recria, perdem seu caráter especifico e passam a fazer parte do processo capitalista propriamente dito.” (p. 59).

Segundo Gorender, com esse procedimento "a realidade sócio-bistórica é violentada e aplainada em benefício de um esquema histórico de fácil manejo, pois se esquiva de enfrentar as diferenciações e especificidades.” (p. 59).

Não acreditamos que as diferenciações e especificidades, enfim, que as particularidades, só possam ser enfrentadas com o uso da categoria modo de produção. Na verdade, seguindo rigorosamente o materialismo dialético, o rigor do discurso é prejudicado se se utiliza conceitos que não estão postos efetivamente quando se utiliza os conceitos como puros universais abstratos, ainda que aplicados a "especificidades" e "diferenciações", baseadas no "material empírico", na "documentação factual”, nas "fontes documentais" etc. (p. 54), pois o 'material' do materialismo dialético não se confunde com o empírico: este é apenas o plano fenomênico, a aparência ou a superfície da realidade objetiva.

Gorender, como muitos outros marxistas, compartilha de uma leitura não dialética do Prefácio de 1857 que o leva a concebê-lo como se fosse a apresentação de uma teoria geral da história. Como o próprio Marx afirmou no referido prefácio à sua obra Para a critica da economia politica (Marx, 1979), o uso das categorias criadas pela economia política para o estudo das sociedades passadas deve ser feito cum grano salis.

Como a questão lógica e metodológica da leitura de Marx é fundamental para nossa discussão, convém esclarecer a visão do método e a leitura de Marx que aqui se abraça, que é o resgate da leitura dialética de Marx realizada por Ruy Fausto. Em seu texto Para uma crítica da apresentação marxista da História: sobre a sucessão dos modos de produção, Fausto (1988, cap. 1) escreve que as categorias criadas por Marx para o capitalismo devem ser vistas não como categorias de uma teoria geral da História, pois seu estatuto teórico nas sociedades passadas é o de conceitos pressupostos, ou seja, como conceitos cujas determinações estão postas, mas aos quais falta a determinação posição.

Em outro texto, intitulado Pressuposição e posição: dialética e significações 'obscuras', Fausto (1988, cap. 2) mostra que tanto na dialética hegeliana como na marxista, a

11 A versão citada por Gorender é a seguinte: Luxemburgo, R. La acumulación del capital. Barcelona: Ed. Grijalbo, 1978.. 
posição do conceito (ou seja, sua existência efetiva) é também uma determinação do conceito. Isto não existe para a concepção kantiana, para a qual a posição é um atributo que só cabe ao objeto (à coisa-em-si), e a pressuposição é um atributo que só cabe ao sujeito. Para as dialéticas de Hegel e Marx, entretanto, é possível tanto a existência de pressuposiçóes objetivas, ou seja, de objetos pressupostos, quanto da posição pensada, ou seja, que os conceitos não são meras representações subjetivas, mas dizem respeito a objetos efetivamente existentes.

Quanto aos objetos pressupostos, escreve Fausto que eles são contraditórios, pois pertencem ao mesmo tempo ao campo do ser e do não-ser. A pressuposição objetiva pode ser pensada na dialética, segundo Fausto, de duas maneiras:

1) o pressuposto como o possível - objetos plenamente determinados, mas aos quais falta a determinação posição (que é a posição efetiva do conceito). Neste caso, a contradição vem do fato de que o objeto, apesar de já ter todas as suas determinações (e, portanto, pertence ao campo do ser), não tem a determinação posição, sendo portanto mera possibilidade ou contingência (pertencendo pois ao campo do não-ser);

2) o pressuposto como posição negada - objetos cuja própria posição é uma negação, ou seja, o objeto ao se pôr nega a si mesmo. A contradição aqui vem não de um objeto pressuposto ao qual falta a posição, mas do fato de que a própria posição do objeto leva à sua negação.

Para o primeiro caso, que é o que está em questão aqui, sem a determinação posição, o conceito permanece como pressuposição, portanto como conceito negado, generalidade negada, e por isso mesmo, apenas um universal abstrato. ${ }^{12}$ A passagem da pressuposição à posição, que neste caso é uma passagem da possibilidade ou contingência à efetividade, exige a negação do não-ser (a negação da negação), ou seja, exige a posição efetiva da generalidade que permite a confecção do conceito. E quando a generalidade é posta, ela se nega em particularidade, pois é histórica, ou seja, é uma abstração real (abstração que se opera no próprio objeto, não como categoria puramente subjetiva). Sobre a categoria trabalho, para ficar num exemplo famoso, escreve Marx, no Prefácio:

"O trabalho parece ser uma categoria muito simples. E também a representação do trabalho, neste sentido geral - como trabalbo em geral. Entretanto, concebido economicamente nesta simplicidade o 'trabalho' é uma categoria tão moderna como são as relações que engendram esta

12 Como mostra Fausto, nesse caso do pressuposto como o possível ou o ainda não posto, a distinção pressuposição/posição é próxima da distinção aristotélica entre potência e ato. 
abstração (...) esta abstração do trabalho em geral não é apenas o resultado intelectual de uma totalidade concreta de trabalhos. A indiferença em relação ao trabalho determinado corresponde a uma forma de sociedade na qual os individuos podem passar com facilidade de um trabalho a outro e na qual o gênero determinado de trabalho é fortuito $e$, portanto, é-lhes indiferente. Neste caso, o trabalho converteu-se não apenas como categoria, mas na efetividade, em um meio de produzir riqueza em geral (...) Assim, a abstração mais simples que a Economia moderna situa em primeiro lugar só aparece no entanto nesta abstração praticamente verdadeira como categoria da sociedade mais moderna." (1979, p. 125-126).

Aqui fica claro que para Marx a abstração presente na categoria trabalho, como trabalho em geral, é uma abstração real, operada pela própria materialidade da vida social na sociedade moderna, e "não apenas o resultado intelectual de uma totalidade concreta de trabalhos." É uma abstração "praticamente verdadeira" (apesar da confusão a que pode levar a tradução, o "praticamente verdadeira" aqui deve ser lido como "verdadeira na prática” e não como "quase verdadeira”).

Assim, para a dialética marxiana, que é materialista, o que confere legitimidade ao conceito, ou seja, o que regula sua adequação ao objeto é o fato de que o surgimento dele está intimamente ligado à existência efetiva do objeto. Enquanto para a dialética hegeliana a passagem da posição pensada à posição objetiva (que é a chamada prova ontológica) é feita sem rigor, pois pensada como um movimento da própria idéia, em Marx adquire rigor, pois é operada a partir de um argumento ontológico objetivo: a posição pensada só pode existir num meio social no qual o conceito tem existência efetiva, ou seja, num meio social no qual antes já se efetuou a posição objetiva do conceito, a posição efetiva da generalidade, o universal concreto. Escreve Marx a respeito de Hegel:

"(...) Hegel cain na ilusão de conceber o real como resultado do pensamento que se sintetiza em si, se aprofunda em si e se move por si mesmo; enquanto que o método que consiste em elevar-se do abstrato ao concreto não é senão a maneira de proceder do pensamento para se apropriar do concreto, para reproduzi-lo como concreto pensado. Mas este não é de modo nenhum o processo da gênese do próprio concreto". E mais a diante: “(...) [a totalidade concreta] não é de modo nenbum o produto do conceito que pensa separado e acima da intuição e da representação, e que se engendra a si mesmo, mas da elaboração da intuição e da representação em conceitos." (Marx, 1979, p. 117). 
Assim, em Marx, para que o sujeito opere a posição pensada é necessário que o próprio objeto tenha efetuado a passagem da pressuposição à posição, ou seja, é necessária a posição objetiva. Mas, como coloca Fausto, para Marx, ao contrário de Hegel, a posição objetiva não está contida na determinação posição, ela continua existindo em sua autonomia, externa ao sujeito do conhecimento:
"O todo, tal como aparece no cérebro, como um todo de pensamentos, é um produto do cérebro pensante que se apropria do mundo do único modo que lhe é possivel, modo que difere do modo artístico, religioso e prático- mental de se apropriar dele. O sujeito real permanece subsistindo, agora como antes, em sua autonomia fora do cérebro, isto é, na medida em que o cérebro não se comporta senão especulativamente, teoricamente." (Marx, 1979, p. 117).

Uma vez que a própria realidade objetiva possibilitou a confecção do conceito, não se pode, a partir daí, usar os conceitos como se fossem categorias que surgiram meramente no pensamento, por um processo de abstração subjetivo, para estudar um passado no qual esses conceitos não tinham existência efetiva. Esses são os limites do conhecimento, onde o marxismo se aproxima do historicismo. Dizer claramente esses conceitos - isto é, dizer que o conceito pertence ao campo do ser - é uma impropriedade, pois, como vimos, antes da posição objetiva ele permanece como pressuposição, pertencendo, pois, ao mesmo tempo, ao campo do ser e do não-ser. Desta forma, a adequação da dialética ao objeto vem exatamente pelo fato de que, para um objeto contraditório, o discurso para dizê-lo deve ser também um discurso da contradição, para apropriar-se dialeticamente da contradição. Caso contrário, ao aplicar-se um discurso "claro", ou seja, o discurso do entendimento, centrado na lógica formal, a um objeto que é "obscuro", isto é, contraditório, a contradição passa para o discurso e o rigor científico se perde.

Essa compreensão da relação entre posição e pressuposição apontada por Fausto já é advertência suficiente para que se tenha cuidado com o uso das categorias criadas por Marx para o capitalismo para estudar sociedades passadas (particularmente pela busca de "leis" baseadas em categorias abstratas), visto que os conceitos da economia política em sociedades passadas, por serem pressuposições, são afetados de negação.

O problema mais evidente com a concepção metodológica de Gorender, a nosso ver, está explícito ainda na primeira seção de seu referido artigo quando, citando Engels, ele separa o "modo histórico" do "modo lógico" do método dialético. O primeiro seria o que "se aplica aos niveis do singular e do particular, mas que não ascende ao nivel categorial sistemático de abordagem da matéria histórica." (p. 44). O segundo seria o "estudo categorial-sistemático ou, se quiserem, estrutural, no sentido de que deve atravessar 
as aparências fenomenais e revelar a estrutura essencial.” (p. 44-45). Gorender diz então que enfatiza o modo lógico do método dialético, com a ressalva de fazê-lo sem suprimir o histórico. Entretanto, e isso se pressente quando ele usa o termo "estrutural" (e ressaltaremos aqui suas semelhanças com o estruturalismo), sua conciliação entre os dois modos se dá de forma frágil, de maneira não dialética.

Isso ocorre porque ele, à maneira dos discursos do entendimento (pagando tributo à distinção kantiana entre sujeito e objeto, e isso ainda que se apresente como antikantiano por diversas vezes), concebe o lógico como sendo apenas o categorial, e concebe o histórico como sendo apenas o "particular" ou "acontecimental" (p. 45), à maneira do historicismo, e não como ontologia, como um devir ou processo de constituição do ser (passagem da pressuposição à posição, ou da possibilidade à efetividade, ou ainda do não-ser ao ser). Desta forma, em vez de se apropriar do processo histórico real (que é lógico-ontológico), há um esforço para encaixar determinações históricas acontecimentais numa estrutura teórica previamente concebida com categorias que, por não terem a determinação posição, são assim puros universais abstratos.

Ora, para a dialética, especialmente a marxiana, tanto o "lógico" (o categorial ou geral) é histórico, visto que a abstração é real e, portanto, particular, como o "histórico" é lógico e geral, visto que é a generalidade posta, universal concreto. É dessa maneira contraditória que se deve compreender a concepção das significações de Marx, ou seja, o discurso deve aceitar a contradição para apreendê-la, reproduzir a contradição real, caso contrário a contradição, que é objetiva, passa para o discurso, mas como contradição vulgar. Como escreve Fausto, sofrer a contradição seria uma "visada clara do objeto obscuro", ${ }^{13}$ quando para o objeto obscuro deve se ter também uma visada obscura, ou seja, afetada de negação. Daí a adequação do discurso dialético, como adequação do objeto obscuro pensado ao objeto obscuro real.

Falta a Gorender, como parece que também faltou ao próprio Engels (pelo menos na leitura que dele faz Gorender), a percepção de que não podem ser tratados em separado os modos lógico e histórico do método dialético, ainda quando se afirma que se irá “juntá-los” depois, pois isso só pode levar a um ecletismo que de nada resolve o conflito entre o positivismo e o historicismo. ${ }^{14} \mathrm{Na}$ verdade, quando se separam os dois (ou quando se os une de maneira não dialética) é exatamente quando surgem as imprecisões historicistas ou positivistas/estruturalistas, ou ainda as ecléticas. Isto porque a dialética não é a rigor um "método" no sentido que se atribui a essa palavra

13 Com a idéia de obscuridade, Fausto (1988, cap. 2) refere-se aos objetos contraditórios, que rompem com os princípios basilares da lógica formal, como o princípio da não-contradição. Assim, enquanto o discurso formal seria aquele que trata apenas de significaçôes "claras", ou seja, apenas a respeito do que se pode dizer que é ou que não é, a dialética trata das significaçôes obscuras, às quais cabe tanto o ser como o não ser.

14 A esse respeito, ver Teixeira (2003, especialmente os capítulos 2 e 3). 
dentro do discurso do entendimento. A dialética é um discurso que é lógico-ontológico, ou seja, método e objeto se determinam reciprocamente, tendo a primazia este último, ao menos no caso da dialética marxiana (não se pode dizer o mesmo, sem ressalvas, a respeito da dialética hegeliana). ${ }^{15}$

Quando Gorender privilegia o "modo lógico", faz precisamente o mesmo que o estruturalismo: tentar encaixar situações factuais em categorias preestabelecidas, universais abstratos. O "modo histórico", reduzido ao acontecimental e materializado nas fontes documentais, acaba tendo caráter secundário e quase que apenas confirmatório e ilustrativo do esquema teórico.

Há ainda outro argumento contra a idéia da existência de modos de produção coloniais. O conceito de Modo de Produção surge a partir do capitalismo, e é inerente à crítica da economia política de Marx, cujos conceitos só poderiam ter sido formulados nessa sociedade, a partir das abstrações concretas efetuadas no e pelo capitalismo. Assim, nos parece que a colonização, bem como o apresamento e o tráfico negreiro, devem ser vistos como um processo histórico efetivo, de constituição do capitalismo enquanto Modo de Produção que une todas as partes do mundo integrando-as numa divisão internacional do trabalho e tendo o capital como sujeito desse processo, que é um processo de constituição de uma história genuinamente universal. Voltaremos a esse ponto na próxima seção.

Vamos agora para outro importante autor do debate, que é Antonio Barros de Castro. No seu texto A economia política, o capitalismo e a escravidão (Castro, 1980), assim como Gorender, o autor destaca, contra o modelo pradiano, a escravidão como categoria central para a compreensão do sistema colonial. Entretanto, ao contrário de Gorender, que busca apreender a categoria escravidão por meio das categorias da Economia Política, com o conceito de modo de produção, Castro tem uma leitura diferente que remete aos limites da Economia Política.

Numa interessante argumentação, escreve que o procedimento desenvolvido por Marx em $O$ capital, buscando as "leis gerais" que regem a produção capitalista, não pode ser repetido para outras sociedades. Isto porque é apenas no capitalismo que se tem de fato a autonomia da esfera "econômica" da vida social ante as demais esferas, é apenas no capitalismo que as relações sociais entre os homens aparecem como se fossem naturais e portanto passíveis de serem estudadas por uma ciência que busca leis gerais e regularidades, e é apenas nesta sociedade, portanto, que o materialismo histórico, e portanto a Economia Política, poderiam ser rigorosamente aplicados. Por exemplo, a respeito do feudalismo, diz o autor:

15 A exposição rigorosa a respeito da concepção dialética das significações, bem como da diferença entre as dialéticas de Hegel e Marx, está em Fausto (1988, especialmente o capítulo 2). 
"O que se pretende frisar é que o feudalismo tem em sua base uma 'substância' histórica - união química entre o econômico e o político - inexistente no capitalismo. Num tal contexto, não tem, pois, cabimento discutir o peso relativo do 'econômico', que simplesmente não existe como tal. Tampouco tem sentido pretender sequer estabelecer a 'lei econômica que preside o movimento desta sociedade'. Em outras palavras, este regime social e sua evolução são rigorosamente intratáveis pela economia politica, e não se pode fazer com ela o análogo do que Marx fez para o capitalismo." (Castro, 1980, p. 84).

Partindo desta concepção, Castro vai analisar as características da economia colonial para mostrar os limites da Economia Política na sua apreensão. Assim, pode-se resumir sua argumentação em três partes:

1) A estrutura da economia colonial foi moldada pela produção de mercadorias, ou seja, produção de valores de troca, e não apenas de valores de uso, como no escravismo patriarcal da antigüidade.

2) Embora esta estrutura tenha sido moldada pela produção de mercadorias, ela também foi moldada pela escravidão, elemento estranho ao capitalismo. Neste aspecto é que ele se diferencia do modelo pradiano e se aproxima de Gorender.

3) A Economia colonial tem, portanto, esta dupla determinação (a produção de mercadorias e a escravidão), e sua apreensão teórica não pode se ater apenas à produção de mercadorias - o "sentido da colonização" -, pois a presença do escravismo torna insuficientes as teorias da Economia Política cujas categorias foram elaboradas para a economia capitalista, de produção de mercadorias. Neste aspecto ele vai então num caminho oposto ao de Gorender, que tem como premissa metodológica a possibilidade de aplicação das categorias da Economia Política, que constituiriam uma estrutura teórica de análise, a todos os modos de produção, apesar de se colocar como crítico do estruturalismo de Althusser.

Para Castro, a economia colonial teria uma parte previsível, ou seja, passível de ser estudada pelas leis da Economia Política (já que é uma sociedade de produção de mercadorias, com as regularidades trazidas pelas relações mercantis) e outra parte imprevisível, regida pela luta de classes (escravos e senhores), cuja motivação é primordialmente política e não econômica. Apenas no capitalismo, em que a extração do excedente da força de trabalho se dá de forma puramente econômica, dentro das leis do mercado (já que juridicamente todos são iguais), é que a luta de classes torna-se de certa forma "previsível" pelas leis da Economia Política. No escravismo (e de resto nas demais sociedades pré-capitalistas), como a coação ao trabalho e a extração do 
excedente são extra-econômicas (baseadas em relações jurídicas de dominação), esta luta de classes não pode ser estudada pelas leis da Economia Política.

Assim, Castro destaca os limites do materialismo histórico para compreender a economia colonial:

"Estas são razões fundamentais que impossibilitam estudar o regime social imperante no nosso passado, através das condições e necessidades da produção de mercadorias. As determinações que dai provêm existem e têm o seu espaço. Limitar-se a elas - e/ou ao seu 'sentido' - no entanto, é tomar os escravos como se apenas emprestassem um colorido especial à história, ou pior, talvez, como se as características por eles introduzidas na economia e na sociedade fossem apenas outras tantas 'irracionalidades.” (op. cit, p. 106).

Ele permanece próximo de Gorender e Ciro Cardoso, entretanto, por destacar a reprodução interna à colônia. Assim, para ele, o "sentido" poderia explicar apenas a implantação do sistema colonial, mas o desenvolvimento posterior deste sistema traria uma dinâmica interna que a idéia de "sentido" era insuficiente para explicar, pois a partir de agora a sociedade colonial deveria reproduzir a si própria:

"A produção em massa de mercadorias cria raizes no Novo Mundo, objetivando-se sob a forma de um complexo aparato produtivo. O 'objetivo' maior desta realidade - o seu 'sentido' se se quiser - lhe é agora inerente: atender as suas múltiplas necessidades, garantir a sua reprodução. Em tais condições o comércio é estruturalmente recolocado e os interesses mercantis - bem como os da Coroa - terão necessariamente que ter em conta as determinações que se estabelecem ao nivel da produção. Em outras palavras, a forma pela qual os interesses externos atuam sobre a colônia passa a depender 'primeiramente da sua solidez e da sua estrutura interna'. O 'projeto' colonial e/ou mercantilista subsiste, sem dúvida: o seu raio de incidência - especialmente em conjunturas adversas - fica no entanto severamente limitado pelo surgimento na colônia de uma estrutura sócio-econômica, com seus elementos de rigidez, suas regularidades, seus interesses e, por último, mas também importante, pelos conflitos que the são próprios." (Castro, 1980, p. 88-89).

A crítica de Castro ao uso das categorias da Economia Política para estudar as sociedades passadas está, a nosso ver, correta. Concordamos no que diz respeito aos modos de produção não serem homólogos, para o que Marx alertou que se deveria ter cuidado ao aplicar as categorias da Economia Política, construídas a partir da so- 
ciedade burguesa (capitalista) para estudar o passado. Assim, a nosso ver, Marx não tinha como objetivo construir uma "teoria geral da história", como parece entender Gorender que, neste ponto, apesar das críticas ao estruturalismo, se aproxima muito de Althusser. E isto ocorre porque Gorender, como os estruturalistas, exagera ao destacar um pretenso caráter cientificista em Marx, ${ }^{16}$ o que torna sua leitura da obra marxiana pouco dialética, particularmente no que diz respeito à relação dialética entre a particularidade e a generalidade dos conceitos, que é essencial à compreensão da concepção marxiana da História.

Entretanto, a limitação da Economia Política apontada por Castro para estudar o período colonial nos parece exagerada. Ele aponta para o caminho oposto ao do estruturalismo e de Gorender, para negar qualquer caráter de generalidade aos conceitos da Economia Política, que não poderiam ser aplicados a outras sociedades em que a dominação e a extração do excedente não fosse de caráter puramente econômico, como ocorre com o trabalho assalariado no capitalismo, e portanto não poderiam ser aplicados ao escravismo colonial. Esta questão metodológica da generalidade dos conceitos é central para a discussão e voltaremos a ela adiante, pois aqui nos deparamos com a questão da legitimidade dos conceitos criados para se apreender a realidade social, ou seja, com a questão da adequação do discurso científico ao objeto.

Por hora, cumpre notar que esta posição de Castro obriga a optar por uma abordagem próxima às vertentes dualistas da historiografia, como as de Roger Bastide e Jacques Lambert, que viam no Brasil uma sociedade dual (um setor moderno, capitalista, e outro arcaico, feudal), e que já tiveram sua crítica a nosso ver mais consistente na obra de Francisco de Oliveira, ${ }^{17}$ Critica à razão dualista. (Oliveira, 2003). No caso de Castro, haveria dois elementos de natureza distinta convivendo simultaneamente - a produção de mercadorias, capitalista, e o escravismo, elemento estranho ao capitalismo - e da combinação destes elementos é que emerge a sociedade brasileira:

"No regime social que aqui se instala há dois teclados; os teclados são dois, mas a música é uma só. Há a produção de mercadorias, com a sua partitura composta de determinaçôes econômicas. E há a escravidão, um velho tema, que permite improvisos de muita força. A teoria desta realidade está por ser produzida. Mas não será negando características

16 Entendemos que a crítica de Gorender seja mais quanto à rigidez do esquema de combinações do estruturalismo, nos quais ele não encontraria espaço para um novo modo de produção escravista colonial do que ao esquema abstrato propriamente dito. Ele tem a mesma concepção de generalidade do uso das categorias da economia política para se estudar outras sociedades, como se constituíssem uma teoria geral da história (ou estruturas conceituais gerais), o que no nosso entender não era o objetivo de Marx, o que ele próprio explicitou várias vezes.

17 Apesar de Oliveira (2003) ter feito sua crítica ao esquema interpretativo dualista analisando a sociedade brasileira já depois de 1930, acreditamos haver um importante paralelo entre sua análise e as discussóes presentes neste trabalho, particularmente com as idéias de Castro como também com as de Fragoso e Florentino. Voltaremos a essa questão adiante. 
fundamentais do regime social, aqui surgido, que ela poderá vir a ser construida. Nesta empresa, como se procurou mostrar neste trabalho, há que resistir a duas tentaçôes: tomar esta realidade como uma história sem determinaçôes próprias, com o que se resvala, inexoravelmente, para a teleologia; ou concebê-la como um sistema sócio-econômico homólogo ao capitalismo e, como tal, passivel de ser apreendido através de uma Economia Politica." (op. cit., p. 106-7).

A primeira tentação, como se percebe, é aquela em que incorreu Fernando Novais, e a segunda, a que incorreram Gorender e Ciro Cardoso. Não nos parece, todavia, um procedimento metodológico correto partir de interpretaçóes dualistas, com a pretensão de se apropriar da totalidade concreta a partir de combinações ou justaposições de elementos estranhos entre si. O procedimento correto e o grande desafio teórico, a nosso ver, seria ver o papel do escravismo dentro da produção de mercadorias, como elemento dela, não como algo exterior e estranho a ela.

Do exposto até aqui identificamos alguns problemas que uma teoria com a pretensão de fazer uma superação das questões ainda não respondidas pela historiografia deveria conseguir resolver:

1) o fato de que o "sentido da colonização", como foi apontado pelas críticas teóricas e também pelos estudos empíricos empreendidos nas últimas décadas, não consegue explicar toda a riqueza de determinações da sociedade e economia coloniais, que se mostraram muito mais complexas do que o modelo previa, havendo pois, de fato, um grau de autonomia ante o capital comercial;

2) que apesar desta relativa autonomia, há problemas lógicos quando se tenta aplicar a categoria modo de produção à economia colonial, dado o caráter dependente da sua reprodução;

3) além do caráter dependente, o uso da categoria modo de produção também encontra dificuldades de aplicação em virtude de a economia colonial ter sido caracterizada, ao mesmo tempo, pela produção de mercadorias e pela escravidão, que em princípio seria incompatível com o capitalismo. Surge então a necessidade de conciliar, teoricamente, a produção de mercadorias com o escravismo, evitando as fáceis soluções de mera justaposição ou combinação de elementos.

Na próxima seção, veremos como os novos modelos teóricos propostos na década de 1990 buscaram lidar com estes problemas. 


\section{OS MODELOS INTERPRETATIVOS DA DÉCADA DE 1990}

Buscando uma nova interpretação que levasse em conta a complexidade das atividades da economia colonial, que não se resumiriam à plantation agrícola nem se subordinavam completamente a ela, dois autores da que se convencionou chamar "Escola do Rio" desenvolveram um modelo alternativo cujo foco principal é a crítica aos dois postulados que derivam dos modelos explicativos anteriores: 1) a reduzida importância do mercado interno da colônia; e 2) a dependência e subordinação da colônia com relação à metrópole. Segundo os autores, estes postulados estão presentes não apenas na versão do "sentido da colonização" (na qual eles incluem Caio Prado Jr., Celso Furtado, Fernando Novais e João Manuel Cardoso de Mello) como também na versão do Modo de Produção Escravista Colonial (Ciro Cardoso e Jacob Gorender).

Para desenvolver essa tese, o trabalho de Fragoso (1998) destacou o conceito de Formação Social para tentar superar os problemas trazidos pelo uso da categoria modo de produção. Na tradição marxista, esta última categoria é vista como uma espécie de tipo ideal ou puro, enquanto a Formação Social seria a forma como se manifesta, fenomenicamente, o modo de produção. Assim, na realidade fenomênica, uma formação social pode conter elementos de diferentes modos de produção, entre os quais um é dominante.

Fragoso destaca que as formas não-capitalistas de produção, ligadas ao mercado interno, que era muito expressivo (como evidenciado pelas pesquisas empíricas), eram essenciais na acumulação da economia colonial:

"A existência de um mercado doméstico e de segmentos produtivos para ele voltados introduz um novo elemento na lógica de funcionamento da formação colonial - referimo-nos à possibilidade de reproduções endógenas. (...) o processo de reprodução desses segmentos se dá em meio ao mercado interno, constituindo-se, assim, em movimentos de acumulação introversas na economia colonial. Disso infere-se uma maior possibilidade de retenção do sobretrabalho na própria economia colonial e, portanto, de autonomia dessa última diante de flutuações externas. (...) Em realidade, a possibilidade de se apreender os movimentos de acumulação endógena à economia colonial prende-se à compreensão dessa última enquanto formação econômico-social. Desse modo, aquela acumulação resultaria, a princípio, da interação mercantil dos processos de reprodução do escravismo colonial com os setores produtivos ligados ao mercado doméstico." (Fragoso, 1998, p. 131-132). 
Em obra mais recente, João Fragoso, juntamente com Manolo Florentino, desenvolvem as idéias que enfatizam a dinâmica interna da colônia, contrapondo-se à idéia do "sentido". Como esta obra conjunta é a versão mais acabada desta nova interpretação, nos centraremos nela.

Os autores destacam em sua obra $O$ arcaismo como projeto (Fragoso e Florentino, 2001) a ascensão da classe dos comerciantes de grosso trato do Rio de Janeiro como nova classe hegemônica - tomando o lugar dos senhores de terras, a partir do fim do século XVIII. A existência dos comerciantes como classe hegemônica é apresentada pelos autores com respaldo em dados empíricos que mostram as grandes fortunas que possuíam e as vultosas transaçóes econômicas e negócios empreendidos por estes, seja na compra e venda de imóveis, terras e escravos, seja no financiamento às atividades produtivas etc. Assim, haveria um predomínio da forma mercantil de acumulação, assentada no capital mercantil residente.

Além de apontar a ascensão desta nova classe hegemônica, os autores buscaram explicar tal preeminência dos grandes mercadores, o que os levou a buscar compreender a própria lógica de reiteração temporal da economia colonial. Em sua argumentação, eles vão defender a importância de processos endógenos (isto é, à margem do comércio atlântico) de acumulação, assentados em um "mosaico de relações não-capitalistas" (como a produção "camponesa", o trabalho livre não-assalariado, a produção escravista de alimentos, a estância gaúcha, entre outros), que conferiam autonomia à economia colonial diante das flutuações do comércio internacional.

A acumulação interna, comandada pelo capital mercantil carioca, é evidenciada pela importância que tinha a praça mercantil do Rio de Janeiro como reexportadora de produtos e escravos e de comprador de produtos de outras regiões da colônia, configurando uma complexa rede de transações triangulares internas à colônia:

\section{"Embora transações triangulares deste tipo não estejam contempladas pelas balanças de comércio, o fato é que eram freqüientes e altamente lu- crativas para o capital mercantil carioca, com os ganhos se realizando no mercado interno brasileiro." (Fragoso e Florentino, 2001, p. 115).}

Como raízes estruturais para o predomínio da forma mercantil de acumulação, os autores apontam dois fatores que tornavam o mercado extremamente restrito: 1) o regime compulsório da produção, assentado em uma frágil divisão social do trabalho, o que torna a circulação monetária débil, com poucas opções de investimento; e 2) a monopolização da riqueza, de forma que poucos homens tinham recursos para pôr o sistema econômico em funcionamento. 
Daí se deriva o poder dos comerciantes, que controlavam a liquidez e demandavam a venda em bloco de grandes lotes de mercadorias, submetendo pequenos comerciantes e varejistas, pois controlavam o crédito. Este poder se estendia, segundo os autores, inclusive para as transações com os agentes metropolitanos, colocando dúvidas sobre a subordinação das atividades domésticas ao capital comercial metropolitano.

Em seus estudos, os autores constatam um paradoxo: por que o setor agrário, produtivo e que gera riqueza, demandava menos investimentos que o mercantil, que apenas esteriliza a riqueza? ${ }^{18}$ E como essa economia sobreviveu e, além disso, cresceu ao longo do tempo, mesmo se concentrando nas atividades mercantis que não criam valor? A resposta dos autores está na estrutura da oferta de fatores: terra, mão-de-obra e alimentos.

Do lado da oferta de terras, a fronteira agrícola aberta e a abundância de terras possibilitavam sua obtenção a baixos custos. Quanto a esse aspecto, os autores não diferem da linhagem historiográfica que combatem, pois todos, e em particular Celso Furtado, destacam a abundância de terras como uma das características fundamentais da economia colonial, que faz com que a exploração econômica mais racional seja a do crescimento extensivo, sem progresso técnico.

No que diz respeito à mão-de-obra, composta por escravos negros, a produção social desta também garantia preços baixos, segundo os autores, porque os cativos eram vendidos abaixo do seu valor, ou seja, fora das leis da equivalência da circulação. Na primeira seção de $O$ capital, Marx explicita as leis da circulação simples, dentro da qual as mercadorias são trocadas por equivalentes, ou seja, por outras mercadorias de igual valor. E mercadorias de igual valor são aquelas que têm igualdade dos tempos de trabalho abstrato necessários à sua produção. No caso do escravo, sua produção é entendida pelos autores como:

"a soma dos gastos, em horas-trabalbo, necessários à produção e manutenção do homem desde seu nascimento até o instante em que ele se transformava em prisioneiro de guerra. Era o seu grupo familiar - e, em última instância, sua comunidade - quem efetivamente o produzia. Antes da mutação em cativo, o individuo era, portanto, uma espécie de repositório de milhares de horas-trabalho despendidas por toda a comunidade. Ora, como a violência representava o meio fundamental pela qual o homem era retirado de sua comunidade e escravizado, o custo social de sua produção não era de maneira alguma reposto." (p. 147).

18 Lembremos que os autores buscam situar-se dentro da perspectiva marxista na qual o processo de valorização, enquanto processo de criação de valor, se dá na produção, e não no comércio ou na esfera financeira, onde apenas se dá a transferência de valor gerado na produção. 
Assim, a captura possibilitaria a venda do escravo abaixo do custo social de sua produção, e os autores entendem por isso que essa acumulação não seria, portanto, capitalista, mas pré-capitalista, pois se baseia na troca de não-equivalentes.

Este argumento que busca mostrar o caráter não-capitalista da acumulação com o comércio de escravos não procede, a nosso ver. Em primeiro lugar, porque o valor para Marx só surge (só tem existência efetiva) quando os produtos do trabalho já são mercadorias antes mesmo de irem ao mercado, ou seja, quando a finalidade da produção é o mercado. Este caráter social do valor é claramente apresentado por Marx na seção sobre o fetichismo da mercadoria. Desta forma, não se pode falar em valor ou em mensuração do valor a partir do "tempo de trabalho" que a família ou a comunidade levaram para "produzir" o futuro cativo, visto que essa "produção" não tinha como objetivo o mercado. Em segundo lugar, se se quer pensar a produção do escravo para o mercado, o que consideramos ser o procedimento correto - com o que então faz sentido falar em "valor", sua "produção" é a própria captura, e então o valor do escravo deve ser calculado tendo em vista o dispêndio de horas de trabalho necessário à sua captura. Lembrando o velho Adam Smith: "Por exemplo, se em uma nação de caçadores abater um castor custa duas vezes mais trabalho do que abater um cervo, um castor deve ser trocado por - ou então vale - dois cervos."19

Quanto à estrutura da oferta de alimentos, os autores buscam acabar com a idéia de autarquia da plantation, mostrando a importância das produçóes de gêneros alimentícios de consumo doméstico para a manutenção da agricultura exportadora. Segundo os autores, havia nos setores voltados ao consumo interno (pecuária e agricultura) uma ampla variedade de relações de produção, que associavam o trabalho escravo, a peonagem e formas camponesas que se assemelhavam à servidão. Assim, concluem os autores:

"Podemos agora pensar nesse mosaico de formas de produção como uma verdadeira formação econômica e social. Seu conteńdo - na verdade, o conteúdo do próprio mercado colonial - seria constituido pelos processos de reprodução de diversas estruturas produtivas, os quais teriam por eixo a reiteração da agroexportação fundada no trabalho escravo. Tal afirmação deve ser, entretanto, matizada. O mercado interno formado por diferentes tipos de produção redefiniria o próprio funcionamento da plantation, pois a recorrência temporal desta última dependeria de recursos endógenos (acumulações internas) à formação colonial. Em suma,

19 Smith, Adam. A riqueza das naçôes. Coleção "Os Economistas", Abril Cultural, 1984, p. 77. Claro que se a produção de castores em cativeiro for possível e menos custosa que sua caça, a primeira será preferida e a nação de caçadores se torna uma nação de criadores de castores. No caso do mercado de escravos no Brasil, ao que tudo indica, era mais atrativo importar o escravo do que a produção local de "gado humano", conforme Castro (1977, p. 206). 
a reprodução da plantation dar-se-ia, ao menos parcialmente, à margem do mercado internacional. Isso the permitivia reiterar-se no tempo apoiando-se em formas coloniais não-capitalistas - o que, além de reduzir seus custos operacionais, the daria uma ampla margem de autonomia diante das flutuações dos preços no mercado externo." (p. 158, grifos meus).

Destacamos no trecho acima as duas expressões que julgamos mais importantes para a discussão. Os autores usam explicitamente a categoria formação social, embora sem explicitar o que entendem pelo termo. Dentro da tradição marxista, a formação social seria a manifestação concreta de um modo de produção dominante, que nunca existe em estado puro, mas convive com resquícios de modos de produção passados e também com elementos da forma futura. Tendo em vista esta noção, surgem dois problemas no uso da expressão que fazem Fragoso e Florentino. Em primeiro lugar, qual é o modo de produção dominante? Assim, os autores, na verdade, apenas se esquivaram da discussão a respeito da adequação do uso da categoria modo de produção na economia colonial, sem resolver esta questão. Evitam, assim, o uso explícito do conceito de modo de produção capitalista ao se referir ao período colonial, embora usem o conceito de formação social, que pede o primeiro, e que a rigor não diz nada sem ele.

Em segundo lugar, se o capitalismo é o modo de produção dominante, o papel dos modos de produção não-capitalistas na estrutura apresentada de maneira alguma é o de meros resquícios que coexistem com o modo de produção dominante, pois segundo os autores, as "formas coloniais não-capitalistas" são essenciais para se compreender a reiteração temporal de toda a economia colonial, bem como sua autonomia ante as flutuações externas - o que recoloca e torna mais complexa a procura pelo modo de produção que seria dominante.

É interessante destacar que o papel que têm tais formas não-capitalistas para esses autores lembra muito o argumento de Francisco de Oliveira em sua obra Critica da razão dualista (Oliveira, 2003 - a primeira edição é de 1973). Nesta obra, Oliveira busca combater as interpretações dualistas, muito difundidas à época (e que aparecem nas obras de Roger Bastide e Jacques Lambert, no modelo de desenvolvimento econômico de oferta ilimitada de mão-de-obra de Lewis, e que também teve influência nos teóricos da CEPAL). Segundo estas interpretações, haveria dois mundos diferentes no Brasil, um moderno (que seria o setor urbano-industrial) e outro arcaico (o setor rural-agrícola), e a raiz dos nossos problemas estaria no fato de que o setor arcaico ${ }^{20}$

20 A idéia de "arcaísmo" aqui, embora distinta quanto ao conteúdo e período histórico da idéia de arcaísmo que dá título à obra de Fragoso e Florentino, tem relação com aquela, e buscaremos desenvolver tal relação adiante. 
impede ou entrava o progresso que seria trazido pelo setor moderno. Oliveira mostra, entretanto, que a existência do setor dito atrasado é fundamental para a dinâmica do setor moderno, ou seja, na verdade o moderno se alimenta do atraso. O subdesenvolvimento (caracterizado pela permanência das estruturas arcaicas) não é, portanto, uma anomalia ou estágio, mas um tipo particular de desenvolvimento capitalista. Este tipo de abordagem não é novo, portanto, na historiografia brasileira, ainda que Oliveira esteja tratando da economia brasileira entre as décadas de 1930 e 1970 do século passado. ${ }^{21}$ Entretanto, Fragoso e Florentino não fazem referência a este texto clássico.

Na verdade, o que Fragoso e Florentino perceberam, a nosso ver, é o poder da forma capital de subordinar a ela todas as demais relaçóes, o que não enfraquece, mas reforça a idéia do sentido da colonização, ainda que numa nova ótica, como buscaremos argumentar adiante.

Outro aspecto importante da obra é o papel atribuído às características da sociedade portuguesa (a nossa metrópole) na definição dos contornos da sociedade colonial, particularmente nas dimensões social e política. A estrutura social portuguesa é caracterizada como parasitária: há uma reduzida parcela de produtores diretos (camponeses) e uma ampla parcela da população (cerca de dois terços), composta pelo clero, fidalgos, mercadores, pescadores, artífices e ociosos, o que tornava extremamente frágil o abastecimento pela produção de alimentos. A expansão ultramarina, com a transferência da renda para a metrópole, mostrou-se uma solução para a perpetuação dessa estrutura parasitária, e não um instrumento para o desenvolvimento capitalista, como na versão de Fernando Novais. A manutenção dessa estrutura arcaica era, na visão dos autores, um projeto social das elites portuguesas, que rumava na contramão do desenvolvimento do capitalismo.

Esta característica da metrópole tem seus efeitos sobre a colônia, gerando aqui também um ideal "arcaizante", que se reflete, por exemplo, no fato de os grandes mercadores, ao acumularem riquezas, abandonarem as atividades mercantis para tornarem-se rentistas urbanos ou senhores de terras e homens, ainda que essas atividades apresentassem taxa de lucro inferior às mercantis. A concentração de poder, advinda da posse de imóveis, terras e escravos, assume aqui o papel das relações de produção. Desta forma, a sociedade colonial não pode ser compreendida sem considerar os as-

21 No que diz respeito ao uso da categoria modo de produção para estudar a sociedade brasileira, é importante mencionar ainda a chamada "Tese Feudal", defendida por intelectuais do Partido Comunista Brasileiro (PCB) como Alberto Passos Guimarães e Nelson Werneck Sodré. Estes autores viam na predominância do latifúndio e das relaçóes de trabalho não-assalariadas no campo brasileiro (as relações "arcaicas") uma razão para defender que o País ainda não havia chegado ao capitalismo (isso já em meados do século XX), e que a sociedade brasileira era uma sociedade feudal. Os defensores da Tese Feudal, tendo em vista uma noção etapista da sucessão dos modos de produção, defendiam uma aliança entre o PCB e a burguesia industrial para construir primeiro o capitalismo nacional e só mais tarde buscar o socialismo, com a idéia de "não pular etapas". Como se sabe, Caio Prado Jr. sempre apresentou resistência a essa tese. 
pectos não-econômicos, particularmente sem ter em vista este "projeto arcaizante" que se baseia na concentração de poder e na reiteração de uma sociedade arcaica e excludente.

Temos, para concluir, duas críticas mais gerais ao modelo interpretativo de Fragoso e Florentino, as quais levam a um questionamento do próprio título da obra. Em primeiro lugar, a idéia de "arcaísmo", presente no título, precisa ser revista, já que a reprodução dessas relações "arcaicas" não nos parece representar um atraso, mas sim a própria forma como o capitalismo nasce e se desenvolve nas colônias, num movimento sistêmico que precede as posteriores relações centro-periferia. Esta noção de um capitalismo que recria e incorpora o atraso em sua lógica aparece não apenas em Francisco de Oliveira, já mencionado acima, como também antes em duas obras importantes. Ela está presente na obra Capitalismo e escravidão, na qual Fernando Henrique Cardoso desenvolve as idéias a respeito de como o capitalismo realizava suas necessidades reproduzindo a escravidão, uma escravidão que é moderna e ao mesmo tempo incompatível com a modernidade. Tal noção aparece também no famoso ensaio de Roberto Schwarz, As idéias fora do lugar, na qual o autor, reconhecidamente inspirado no próprio Fernando Henrique (ver Schwarz, 1998, p. 16), mostra o mesmo movimento contraditório no plano das idéias, ou seja, mostra como o atraso das idéias e das instituições tinham uma racionalidade na forma como o capitalismo se desenvolve em nossa sociedade, contradição explorada com maestria por Machado de Assis.

Em segundo lugar, e voltando à discussão sobre a teleologia e a questão do sujeito que iniciamos a partir da interpretação de Fernando Novais, a idéia de "projeto", também presente no título, parece referir-se a um sujeito consciente - no caso, uma classe, ou as elites - na reiteração de tal sociedade "arcaica". O arcaísmo aparece assim como um projeto das elites, de uma classe social, com o que os autores enfatizam então a dimensão política da reprodução e da dominação social, em detrimento da que seria a reprodução e dominação "econômica”. Esta última é a que Marx enfatiza quando escreve que o capital é um sujeito automático, um sujeito não consciente, e no qual os aspectos políticos são derivados do fato de os agentes - as classes - serem meros suportes do capital, apenas personificações de categorias econômicas.

Os problemas acima derivam de uma visão, a nosso ver equivocada, que os autores compartilham de certa forma com o próprio Gorender, do que seria um "capitalismo ideal", quando o mais importante é reconhecer que "nem a escravidão é necessariamente arcaica, nem o capitalismo assegura o dominio do trabalho livre (...)", e também que "(...) o capitalismo tomado como um movimento global engendra significações contraditórias, mesmo em relação às suas categorias centrais, que não se universalizam..” (Schwarz, 1998, p. 16-17). Assim, não há que se evitar falar de capitalismo na sociedade colonial, nem há que se referir a "relações não-capitalistas". As atividades econômicas, indepen- 
dentemente das formas de organização social (relações de produção) sob as quais se apresentassem, estavam todas subordinadas à mais importante das formas: a forma capital. Ou seja, estavam todas integradas ao movimento global do capital. E em seu movimento, o capital enquanto forma ( $\left.\mathrm{D}-\mathrm{M}-\mathrm{D}^{\prime}\right)$, na busca cega pela valorização infinita, prescinde, se necessário, do seu conteúdo, seja utilizando-se de relações de produção não burguesas, como o trabalho escravo, seja prescindindo da própria produção, como nos períodos em que a esfera financeira torna-se o centro da valorização e o movimento do capital abrevia-se para a forma D - D', o que Marx, na seção V do livro III de $O$ capital, chamou de capital portador de juros. Voltaremos a essas questões na conclusão.

Vamos apresentar agora o outro modelo interpretativo, proposto por Iraci Costa e Julio Pires. Mas antes, para melhor compreender a posição dos autores, apresentaremos algumas críticas que Costa (sozinho e em co-autoria com outros autores) já vinha desenvolvendo ao modelo de Fragoso e Florentino, e que estão em sintonia com algumas críticas que já desenvolvemos anteriormente.

Como vimos, a interpretação de João Fragoso e Manolo Florentino radicaliza a visão, contrária à idéia de "sentido", de que a economia colonial tinha uma reprodução autônoma, que o processo de acumulação no interior da economia colonial era o principal fator para compreender a reprodução desta sociedade. Daí advém uma das críticas de Costa e Motta a esse modelo, para a qual os autores buscam apoio no próprio Ciro Cardoso, insuspeito de ser um defensor da idéia de "sentido":

"Tendo combatido por muitos anos as posturas que enfatizam unilateralmente as relaçôes metrópole-colônia ou centro-periferia, a extração de excedentes, o capital mercantil (hipostasiado em 'capitalismo comercial') e mais em geval a circulação de mercadorias como locus explicativo privilegiado, só posso me regozijar com esses novos e sólidos argumentos. Desde que também neste caso, não se ceda à tentação de mais uma ênfase unilateral. (...) não estarão esquecendo exageradamente, empurrando um tanto para fora do horizonte, a dependência colonial e neocolonial - e as determinações e condicionamentos que ela sem qualquer dúvida implicava (ainda que tais análises tenham demonstrado que algumas das determinações imputadas a fatores externos eram falsas)? Fique como questão a ser pensada esta minha dívida.” (Cardoso, 1988, p. 58).

Ou seja, a crítica de Ciro Cardoso procura evitar uma posição extremada à idéia de sentido que implica esquecer que a economia colonial era dependente, embora algumas das suas determinações que foram imputadas a fatores externos (ao "sentido") não eram explicadas por eles (conforme a pesquisa empírica demonstrou fartamente). 
A questão da dependência, que remete à questão da totalidade, já discutimos na seção anterior na crítica aos argumentos de Gorender.

A outra crítica de Costa e Motta a Fragoso é que "o entendimento da economia colonial enquanto formação econômico-social encobre, mas não resolve, a impropriedade presente na utilização do conceito de modo de produção ('problema' que Fragoso, aliás, compartilba com Ciro Cardoso e Jacob Gorender).” (Costa e Motta, 1995, p. 29).

Assim, os autores resgatam idéias presentes em textos do próprio Costa $(1985,1995$ e 1999), nos quais o autor critica o uso da categoria modo de produção para se estudar o período colonial. Nestes textos, o autor defende que tal impropriedade está no fato de que Marx concebeu os modos de produção não como uma teoria geral da história, mas como um continumm histórico-lógico próprio da Europa Ocidental, continumm este do qual o capitalismo é o ponto culminante. E o capitalismo é o ponto culminante no sentido de que a partir dele a história se fez universal, pois o capitalismo tende a exportar-se a si próprio, homogeneizando as relações sociais nas distintas sociedades e áreas do planeta, por meio do desenvolvimento nunca antes visto das formas mercadoria, dinheiro e capital. Todas as áreas do mundo ficam então unidas pelo capital e pelo capitalismo. Assim, não faria sentido falar-se em outros modos de produção depois de fundada a história universal pelo capitalismo, e o autor insere a sociedade colonial como uma sociedade que se desenvolve correlatamente ao desenvolvimento do capitalismo, ou seja, como uma sociedade posta pelo capital e cujo desenvolvimento resultou no capitalismo.

Além disso, criticando a idéia de uma teoria geral da história e das revoluções, ou seja, da passagem de um modo de produção para outro, escreve Costa:

"(...) a gênese de um modo de produção pode ser única, específica, sendo impossivel, portanto, confundir os constituintes genéticos - elementos constitutivos bem como as inter-velações que os vinculam - de um modo de produção com os de outro. Ademais, à medida que não tem de haver, necessariamente, apenas um padrão genético, torna-se impossível o estabelecimento de uma lei, ou conjunto de regularidades, que explique, de maneira abrangente e genérica, a passagem de um para outro modo de produção, ou seja, é impossivel formular-se uma teoria geral das revoluções. Além disso, o próprio funcionamento interno bem como a eventual 'dinâmica' ou 'rigidez' de cada modo de produção não são passíveis de equacionamento único, pois poderão ser peculiares a cada um deles. Logo, tanto pela sua gênese como pelo seu 'funcionamento', os modos de produção podem diferir entre si. Disto se conclui que eles não são isonômicos, 
vale dizer, não existe um conjunto único de leis ou regularidades que os reja." (Costa, 1999, p. 2).

Ainda segundo Costa, além de não serem isonômicos, os modos de produção também não são homólogos, ou seja, não há necessariamente correspondência entre todos e cada um dos elementos constitutivos dos modos de produção, e estes elementos nem sempre se repetem em modos de produção diferentes, ou aparecem com funções ou papéis totalmente distintos. Desta forma, não há como "emparelhar" os modos de produção para compará-los por meio de um conjunto único e abstrato de conceitos com pretensão de generalidade, o que foi feito pela vulgarização do marxismo a partir de Stálin, e também tanto pelos estruturalistas quanto pelo próprio Gorender que os critica.

Assim, a partir de uma leitura de Marx segundo a qual os modos de produção representariam não uma teoria geral da história, mas apenas um continumm históricológico próprio da Europa Ocidental (portanto um "sentido" reconstruído a posteriori pelo cientista, não um a priori teleológico e nem a construção de puros universais abstratos), Costa defende que os modos de produção não são nem isonômicos nem homólogos, aproximando-se da crítica de Barros de Castro, pois é uma crítica que aponta para os limites da utilização dos conceitos da economia política. Entretanto, como defenderemos adiante, o modelo proposto por Costa encontra elementos de generalidade no escravismo colonial que permitem, ao contrário da crítica de Castro, estudá-lo com as categorias da economia política de Marx. Estes elementos de generalidade, como veremos, são encontrados a partir de uma retomada da idéia do "sentido", de Caio Prado Jr., e esta retomada assume, entretanto, a forma de uma superação dialética, ou seja, que supera e ao mesmo tempo conserva a idéia do "sentido da colonização".

Passemos agora ao modelo interpretativo proposto por Julio Pires e Iraci Costa (Costa e Pires, 1994 e Pires e Costa, 2000), para ver como os autores buscam resolver esta tensão entre, de um lado, os limites do uso dos conceitos da economia política, apontados com certa razão por Castro e, de outro, a existência de determinaçốes reais que parecem permitir (e pedir) o uso das categorias da economia política de Marx no período colonial.

O modelo teórico destes autores tem como centro a consideração das formas do capital estudadas por Marx. Estas seriam três: o capital comercial, o capital usurário e o capital industrial. Como se sabe, as duas primeiras formas estiveram presentes em quase toda a história, não têm raízes em nenhum modo de produção, e são formas consideradas parasitárias, porque não se reproduzem autonomamente. Apenas o capital industrial tem autonomia, ou seja, apenas esta forma do capital reproduz a si própria, 
pois a valorização se dá na esfera da produção, na criação de valor pelo trabalho. $\mathrm{O}$ trabalho socialmente necessário permite a reprodução dos trabalhadores, e o trabalho excedente gerado é apropriado pelo capitalista como mais-valia, fonte dos lucros que poderão ser reinvestidos na produção. Assim, o ciclo do capital industrial repõe as próprias condições necessárias para se reiniciar o processo, permitindo, portanto, a reprodução do capital, que se torna um sujeito automático.

Pires e Costa defendem que existiu ainda uma outra forma do capital, que eles chamam de capital escravista-mercantil. Esta forma do capital, como o capital industrial, é caracterizada pela produção e extração de excedente, entretanto com uma peculiaridade: a geração do excedente se dá com mão-de-obra escrava, e não com trabalho assalariado, como seria típico do capitalismo.

Assim, apoiando-se em citações de Marx, Pires e Costa (2000) chegam a três conclusões:

1) "a escravidão localizada não é incompativel com o modo de produção capitalista, mas com o desenvolvimento do mesmo e, portanto, irremediavelmente fadada ao desaparecimento;

2) estamos em face de um escravismo produtor de mercadorias (escravidão puramente industrial) e dependente dos mercados mundiais aos quais deve sua existência

3) os escravistas são capitalistas, vale dizer, acrescentamos nós, personificam o capital escravista-mercantil." (Pires e Costa, 2000, p. 90).

O primeiro ponto apresentado defende que o capitalismo, em seu desenvolvimento, pode eventualmente utilizar-se da escravidão. Foi o que teria ocorrido nas colônias americanas, que teriam passado por um lento e contraditório processo de formação/ incorporação/adequação ao capitalismo:

"A nosso juizo, só há uma maneira de apreender tal processo [o periodo colonial no Brasil - RAT]: cumpre assimilá-lo enquanto tal, vale dizer, como processo histórico concretamente dado. Este é o programa que nos cabe desenvolver; embora dos mais complexos, podemos sumariá-lo com poucas palavras: é preciso descrever como se deu o processo de 'formação/ incorporação/adequação' da sociedade brasileira 'segundo o/ao' modo de produção capitalista, o qual se deve tomar, a um tempo, como causativo e resultante do aludido processo." (Costa, 1995, p. 2). 
Aqui, Costa defende que não se deve ver o período colonial buscando lá outro modo de produção. Como já vimos anteriormente, para este autor, uma vez fundada a história universal pelo capitalismo, só faz sentido falar-se em capitalismo, e o processo de formação da sociedade brasileira é inseparável do desenvolvimento do capitalismo. Os dois outros tópicos acima completam o quadro: o escravismo que se produziu aqui é um escravismo produtor de mercadorias com vistas à valorização do valor, e assim o nosso escravismo pode ser estudado da perspectiva da economia política, ou seja, com os agentes sendo vistos como personificações de categorias econômicas (contrariamente às opiniões de Castro). Isto é possível, acrescentamos nós, pois o capital é o sujeito deste processo, e os homens são, portanto, apenas suportes desta categoria econômica.

É exatamente pelo fato de o capital ser o sujeito deste processo, por ser ele o responsável pela universalidade e pela generalidade, que se torna legítimo que nosso período colonial seja estudado pelas categorias da economia política. Assim, Pires e Costa vêem a adequação da generalidade dos conceitos, coerentemente com a postura do materialismo dialético, na própria realidade concreta, que é a da inserção do período colonial no processo mais amplo de constituição do capitalismo.

Cabe agora compararmos esta postura com uma questão que colocamos à obra de Fernando Novais. Como destacamos anteriormente, há um problema lógico-teórico se, para defender Novais das acusações de teleologia, recorrêssemos à consideração do capital comercial como sujeito do processo que leva à acumulação primitiva de capital. Isto porque, como se sabe, o capital comercial não é uma forma autônoma, e portanto não pode se constituir como sujeito dando origem a uma totalidade. Novais, apesar de aparentemente não se dar conta deste problema ou de não enfrentá-lo, contornao, de uma forma que não é rigorosa, com o uso da categoria capitalismo comercial. Entretanto, esta categoria é imprópria dentro da perspectiva marxista, visto que o capital só ganha autonomia quando o conteúdo da relação formal $\mathrm{D}-\mathrm{M}-\mathrm{D}$ ' é a produção e extração do excedente, a partir do momento em que a força de trabalho se encontra disponível no mercado como mercadoria a ser utilizada no processo produtivo.

Entretanto, Costa e Pires, a nosso ver, conseguiram superar este problema por meio de uma categoria, o capital escravista-mercantil, que antecipa uma característica do capital industrial, ${ }^{22}$ que é o fato de a valorização se dar com base na criação de exce-

22 A nosso ver, o capital-escravista mercantil antecipou outra característica do capital industrial. Se esta forma do capital não tinha a relação de produção capitalista típica (o trabalho assalariado), ela desenvolveu bem antes do capital industrial, entretanto, as forças produtivas capitalistas. Como mostra Castro (1977), os engenhos tinham uma divisão do trabalho avançada que antecipou a própria divisão taylorista do trabalho. Faltava, com relação ao século XX, o componente fordista que sustentou o regime de acumulação fordista/keynesiano (para usar uma expressão da escola regulacionista), que era o consumo de massas, visto que os escravos, ao contrário dos trabalhadores da indústria fordista, não 
dente por meio da produção de mercadorias e não apenas no comércio ou na cobrança de juros, que apenas transferem ou redistribuem o produto. ${ }^{23}$ Assim, se por um lado a crítica de Gorender ao circulacionismo leva a uma posição extremada no sentido de se buscar um novo modo de produção, com o deslocamento da esfera da circulação para a esfera da produção, a categoria capital escravista-mercantil retoma a esfera da produção, sem precisar, entretanto, recorrer à categoria modo de produção. Esta característica do capital escravista-mercantil, de ser produtor de mercadorias, permite, a nosso ver, falar no capital como sujeito durante o período colonial, ou seja, com o capital escravista-mercantil sendo sujeito de um processo que culminará com o desenvolvimento pleno do capital industrial e posteriormente levará à própria superação do capital escravista-mercantil.

Cabe lembrar que para a dialética materialista de Marx é a generalidade concreta (generalidade posta) que legitima a generalidade dos conceitos, que os conceitos são, portanto, universais concretos (e não apenas universais abstratos, como na concepção de Kant que norteia a visão convencional de ciência, guiada pela lógica formal). A adequação do discurso científico ao objeto para Marx, portanto, se dá pelo fato de na própria realidade a abstração ter sido efetuada. No presente caso, da sociedade colonial, a adequação dos conceitos da economia política se dá exatamente pelo fato de as formas mercadoria e capital trazerem a generalidade posta e conduzirem o "sentido" da dinâmica social.

É este resgate do "sentido", do fato de nossa sociedade ter-se constituído dentro do movimento mais geral de constituição do capitalismo, que traz a adequação ao uso dos conceitos da economia política para o estudo de nossa sociedade. Não naturalmente de todos os conceitos, como o de modo de produção, o que seria uma categorização arbitrária e subjetiva, ou seja, um idealismo que parte de categorias preconcebidas, que nada têm que ver com a realidade concreta do período colonial e nem com o materialismo dialético de Marx. A adequação se dá apenas àqueles conceitos que têm existência efetiva na realidade colonial, o que, no caso, é o conceito de capital, ainda

faziam parte do mercado consumidor para os bens que produziam. Ou seja, dentro da base econômica, no seio da qual há uma forma (relações de produção) e a matéria (forças produtivas), embora no plano da forma a colônia não apresentasse as relações tipicamente capitalistas (trabalho assalariado), no plano da matéria antecipou o próprio desenvolvimento da divisão do trabalho que na Europa viria apenas com a Revolução Industrial. Esta observação torna ainda mais complexa a discussão clássica a respeito da adequação do escravismo ao desenvolvimento das forças produtivas. Não há espaço para esta questão neste trabalho.

23 Uma importante discussão, que não poderemos desenvolver neste trabalho por motivos de espaço, é a da existência do valor na sociedade colonial, e portanto a da possibilidade de se chamar de mais-valia o excedente gerado pela produção escravista, já que Marx usou o termo falando da exploração de trabalho assalariado. Costa e Pires utilizam a expressão ao dizerem que o escravismo moderno era produtor de mais-valia. A nosso ver, esta afirmação exige uma análise mais rigorosa do conceito de valor, e por isso preferimos utilizar, por enquanto, a expressão excedente, mais geral, ainda que esse excedente se apresente sob a forma monetária. Esta questão deverá ficar para trabalho posterior. 
que seja uma forma bastante peculiar do capital, que sequer havia sido tratada pelo próprio Marx.

O resgate da idéia de "sentido" se evidencia, assim, nas características desta nova forma do capital, o capital escravista-mercantil. Entretanto, uma observação importante deve ser feita. Ainda que, ao contrário das formas do capital comercial e usurária, esta forma não seja parasitária, pois ela está assentada, como o capital industrial, na produção de mercadorias (e não apenas na sua circulação e redistribuição), ela não é autônoma como o capital industrial, não podendo dar origem a um modo de produção específico, como defendido por Gorender:

"Como evidenciado, o capital escravista-mercantil, por não trazer implicita a plasticidade do comercial e usurário, é imediatamente dependente de uma especifica relação de produção (a escravista) e igualmente dependente de especificos modos de produção (o escravista e o capitalista). Assim (...) tal forma não traz em si seus pressupostos não sendo capaz, portanto, de per se, repố-los; vale dizer, as condiçôes objetivas de sua existência e subsistência lhe são externas e dadas pelos modos de produção retro assinalados. Logo, a forma capital escravista-mercantil é incapaz de dar suporte a um modo de produção que lhe seja próprio e que dela decorra." (Pires e Costa, 2000, p. 91).

Assim, apesar de surgir paralelamente ao desenvolvimento do capitalismo, esta forma do capital é incompatível com o desenvolvimento do mesmo, noção esta que está presente na análise da relação entre capitalismo e escravidão presente em Cardoso (2004). Mas é nesta situação contraditória, negativa, que ela deve ser considerada.

O papel da categoria capital escravista-mercantil na solução dos problemas teóricos discutidos neste artigo é tratado por Costa em outro texto: Repensando o modelo interpretativo de Caio Prado Jr. (Costa, 1995). Falando da limitação do modelo pradiano, escreve o autor:

“(...) as articulaçôes presentes na sociedade brasileira sobrepujavam largamente um mero empreendimento dirigido pelo capital comercial e imediatamente voltado para o mercado mundial e dele totalmente dependente. Neste sentido tratava-se de uma economia com expressivos traços de integração endógena e que comportava uma gama diversificada de atividades produtivas votadas para o atendimento de suas próprias necessidades, dando-se, também, processos internos de acumulação. Disto decorria a geração, na órbita doméstica, de condições que permitiam um espaço econômico relativamente autônomo vis-à-pis a economia inter- 
nacional e o capital comercial, espaço econômico este ao qual, ademais, deve-se atribuir expressivo contributo no que tange à formação da renda e do produto." (Costa, 1995, p. 14).

Não obstante, o próprio autor afirma não ser seu objetivo negar (em sentido vulgar, não dialético) o modelo pradiano:

"Do acima exposto pode-se inferir, esperamos que de modo claro, nossa postura com respeito ao modelo interpretativo de Caio Prado Jr. Não pretendemos negá-lo, mas, qualificando-o, evidenciar a possibilidade de superá-lo de sorte a chegarmos a uma nova sintese, adequada às realidades com quais nos deparamos quando observada a evolução da sociedade e da economia brasileiras à luz de estudos recentes." (Costa, 1995, p. 18, grifos no original).

Assim, a melhor maneira de ver seu projeto é a partir da expressão alemã Aufhebung, que é a que melhor designa a negação dialética, pois tem ao mesmo tempo o sentido de "negar" mas também de "conservar" e "superar". Assim, Costa propõe três frentes teóricas para superar o modelo pradiano. A primeira é no campo metodológico: explicitar as mediações, que em Caio Prado não existem, entre a essência da sociedade colonial, seus determinantes em última instância (o "sentido"), e a sua aparência (plano fenomênico, ou seja, a complexidade da economia colonial).

A segunda é no campo abstrato, na compreensão da acumulação na economia colonial e do papel desempenhado nesta pelo capital comercial e pelo capital escravistamercantil. Este último é visto como o principal elemento da necessária mediação no campo metodológico, mediação entre o capital comercial e as condições internas da acumulação. Daqui percebe-se que a crítica a Caio Prado Jr. é que o seu modelo coloca nossa economia como uma projeção imediata do capital comercial, quando na verdade ela era mediada pelo capital escravista-mercantil, que lhe conferiu traços fenomênicos (no plano da aparência) específicos e não explicados apenas pela essência representada pelo capital comercial.

A terceira é na esfera do concreto, na qual defende o autor uma reformulação dos setores econômicos pensados por Caio Prado Jr., pois a bipartição feita por ele (grande lavoura escravista e agricultura de subsistência) é insuficiente para apreender toda a gama de articulações econômicas da colônia.

É interessante notar que Costa trabalha, sendo fiel ao próprio Marx (e Hegel), com distintos níveis da realidade: o nível da essência e o da aparência (ou realidade fenomênica). Assim, destaca que a teoria e suas categorias de análise devem não apenas explicar aquela essência (o que fez Caio Prado Jr.), nem tampouco ater-se à aparência 
(como as críticas empíricas), mas deve principalmente explicar as mediações entre a essência e a realidade fenomênica.

\section{CONCLUSÕES}

Buscamos mostrar neste trabalho como distintos olhares metodológicos da obra marxiana levaram a distintas interpretações do período colonial. No plano metateórico, demos particular atenção à existência de uma tensão na historiografia que retoma, de certa forma, o debate entre a visão historicista do conhecimento, segundo a qual os conceitos são históricos, particulares, e assim os conceitos criados para estudar uma sociedade não podem ser generalizados para o estudo de outras; e a visão positivista e também a estruturalista, que buscam os "invariantes universais", ou as leis gerais que regem as diferentes sociedades. No plano teórico, enfatizamos as discussões a respeito da utilização dos conceitos da economia política marxista (modo de produção, formação social, relações de produção e capital), e também as discussões a respeito da importância relativa do mercado interno da colônia, com a correspondente discussão sobre a autonomia da economia colonial em face das flutuações do mercado internacional (e as "críticas empíricas" que vieram questionar a idéia do "sentido"). Apesar de termos feito aqui as distinções entre os planos metateórico, teórico e empírico, nunca é demais lembrar que estes planos estão inter-relacionados, e ao longo do texto buscamos explicitar a dificuldade desta separação, particularmente quando se trata de uma abordagem dialética.

Na primeira e segunda seções fizemos uma exposição sobre o modelo pradiano e seus desenvolvimentos. O principal foco das críticas "empíricas" a este modelo era a falta de autonomia da economia colonial que decorre de sua lógica, o que mais tarde foi falseado pelas pesquisas empíricas.

Quanto às críticas "teóricas", apresentamos na terceira seção as de Barros de Castro, Ciro Cardoso e a de Jacob Gorender. Este, partindo das críticas de Ciro Cardoso ao que seria um circulacionismo no modelo pradiano, ou seja, das críticas à ênfase na circulação e partindo então da proposição de que o estudo da colônia deveria se centrar nas relações de produção, buscou utilizar as categorias de Marx, particularmente as relacionadas ao conceito de modo de produção, para estudar a sociedade colonial. Defendeu, assim, que esta se constituiu em um novo modo de produção, o Modo de Produção Escravista Colonial. Barros de Castro criticou o uso da categoria modo de produção, defendendo que a economia colonial tinha duas faces: uma capitalista, que poderia ser estudada pelas leis da economia política, mas outra escravista, cuja dominação era política e não econômica, e que esta trazia à economia colonial um caráter 
de imprevisibilidade, pois não poderia ser apreendida pelas categorias da economia política.

Assim, se Gorender e Cardoso têm uma visão metodológica e uma leitura de Marx que implica conceber generalidade aos conceitos da economia política marxista (aproximando-se do positivismo e também do estruturalismo), Castro tem uma compreensão de que estes conceitos não podem ser utilizados para outras sociedades, pois seriam próprios da economia capitalista (aproximando-se da concepção historicista do conhecimento). Entretanto, este autor propõe uma abordagem que nos parece frágil, pois é dualista, ou seja, propõe a busca de uma explicação para o período colonial que se baseia numa mera justaposição ou combinação de elementos de diferentes sociedades.

Se nem todos os conceitos criados para a sociedade capitalista podem ser estendidos para analisar sociedades passadas, é preciso, entretanto, evitar o erro extremo de se dizer que não se pode usar a Economia Política para se estudar o escravismo, pelo menos quanto ao escravismo moderno. A adequação da abstração científica e, portanto, do caráter da generalidade do conceito em Marx, como se sabe, está exatamente no fato de a abstração ser real, processar-se na materialidade da vida social e, portanto, ser antes atributo do objeto e não apenas categoria arbitrária do sujeito (como na tradição de Kant da qual parte o moderno positivismo). Assim, é possível estudar o período colonial a partir dos conceitos da Economia Política, mas apenas a partir daqueles conceitos que de fato têm o atributo da generalidade posta, isto é, generalidade efetivamente existente, e que por isto se nega em particularidade.

Como notou Marx, a sociedade capitalista é uma máquina de abstrair, ou seja, uma sociedade que produz universais concretos e que assim se universaliza e tende a homogeneizar as relações sociais no mundo, exportando sua determinação característica, a forma capital ( $\left.\mathrm{D}-\mathrm{M}-\mathrm{D}^{\prime}\right)$.

E a forma capital estava presente na sociedade colonial, foi o fundamento do escravismo e da constituição desta sociedade, ao contrário do escravismo patriarcal da antiguidade, onde ela só aparecia esporadicamente. Assim, a partir da forma capital, particularmente da forma capital escravista-mercantil, é possível dizer que o capital era o sujeito que movia a sociedade colonial, e que trouxe a generalidade a partir da qual tornou-se legítima e adequada ao objeto a utilização da Economia Política para tratar do escravismo colonial (embora não com o uso da categoria modo de produção, que não faz sentido).

Concordamos assim com a posição de Costa, segundo a qual a sociedade colonial deve ser estudada como sendo um processo de formação/incorporação/adequação daquela 
parte do planeta ao capitalismo, e que é aí, neste "sentido" essencial, que está a universalidade concreta que permite o uso da universalidade também dos conceitos da economia política, particularmente pela presença marcante e determinante da forma capital, que trouxe consigo uma divisão internacional do trabalho sob a égide da valorização do valor.

Além disso, a categoria capital escravista-mercantil nos parece extremamente adequada para explicitar as mediações que não apareceram no modelo pradiano entre o capital comercial e as formas internas de acumulação, tão enfatizadas por Fragoso, abrindo caminho para a superação daquele modelo (entretanto, esta tarefa ainda está por ser realizada). Tal categorização também evita o erro oposto ao de Caio Prado Jr., que destacou a essência ante o plano fenomênico, que é ater-se ao plano fenomênico (a aparente autonomia da economia colonial) e esquecer-se da essência (sua relação de dependência com relação ao desenvolvimento do capitalismo no plano mundial).

O modelo proposto por Fragoso (1998) e Fragoso e Florentino (2001) incorre exatamente no outro erro apontado, que é privilegiar o nível da aparência, dos fenômenos, por meio do que eles chamam de "mosaico de formas não-capitalistas de produção", e atribuir à acumulação que se dá nestes interstícios sociais "não-capitalistas" um papel preponderante na reprodução da sociedade colonial, esquecendo-se do seu caráter dependente, e esquecendo-se de que essas relações "não-capitalistas" foram criadas pelo próprio movimento do capital.

Desta forma, a partir de um olhar metodológico, a interpretação trazida por Costa e Pires é a mais coerente com a dialética marxiana, pois ela a supera, conservando os momentos do historicismo e do positivismo, de uma forma dialética e materialista. É dialética, pois percebe a existência das abstrações reais, e portanto da contradição, já que quando o universal se torna concreto ele se nega em particularidade. Assim, o momento do positivismo está conservado, pois há o momento da abstração (da generalidade). Da mesma forma, o momento do historicismo também é conservado, pois a abstração é real, empreendida pelo próprio objeto, e assim ao mesmo tempo que é geral, a abstração é também particular, pois é histórica.

E além de dialética, é materialista, pois a posição do conceito é antes posição efetiva da coisa, ou seja, a abstração surge antes na materialidade da vida social para depois ser apreendida pelo sujeito do conhecimento. O conceito não é assim mera subjetividade, não é apenas um universal abstrato, mas universal concreto, que como tal se nega em particularidade. A adequação dos conceitos da Economia Política é garantida, então, pelo próprio objeto: pelo fato de o capital ser o sujeito histórico do processo e conferir o "sentido" do movimento histórico, o objeto é colocado como exterior ao 
sujeito do conhecimento e torna-se passível de ser estudado como uma coisa, não no sentido positivista, mas como coisa social.

Em suma, é pelo fato de o capital ser o sujeito do processo de constituição da sociedade brasileira no período colonial - ainda que não como capital industrial, mas sob a forma do capital escravista-mercantil - e por ser o capitalismo ao mesmo tempo causativo e resultante deste processo, exatamente por isto a idéia de "sentido" 24 de Caio Prado Jr. não pode ser descartada: é necessário, como faz Costa, encontrar as mediações entre o "sentido", no plano abstrato, da essência (abstrato não por ser puramente ideal ou teleológico, mas porque o próprio capital realiza abstrações reais) e a complexidade da economia colonial no plano concreto-fenomênico. A categoria capital escravista-mercantil nos parece ser, assim, um frutífero caminho para desempenhar esta tarefa.

Além dessa justificativa de caráter mais propriamente lógico-metodológico para a defesa do modelo baseado no capital escravista-mercantil (sua adequação dialética que conserva tanto os momentos do positivismo como do historicismo, superando-os), temos outra que diz respeito à própria noção de capitalismo enquanto um sistema histórico e mundial, o que nos leva a repensar a noção do "sentido da colonização", tal como proposta por Caio Prado Jr., e também a noção do "sentido profundo da colonização", de Fernando Novais.

Nossa argumentação aqui se desenvolve numa visão do capitalismo que não reduz esse conceito apenas à busca da extração do excedente baseada no trabalho assalariado. Damos destaque à forma capital e ao seu poder de prescindir das relaçôes de produção tipicamente burguesas ou mesmo do conteúdo dessa relação, que é a extração de excedente no interior da produção.

Esta visão, por sua vez, está ligada à consideração do capitalismo como um modo de produção mundial, que não se restringe a um território, como o fazem as interpretações que buscam ver modos de produção em cada país. O capitalismo deve ser visto como um todo orgânico, cujos traços apontados por Marx não são necessariamente generalizados a todos os locais para onde se expande o capitalismo, ao contrário do que Marx parecia acreditar ao advertir o leitor da atrasada Alemanha, no prefácio à edição Alemã de $O$ capital, com a expressão "de te fabula narratur", argumentando que as categorias ali apontadas, ainda que tenham sido desenvolvidas tomando-se como ponto de partida a Inglaterra, se estenderiam em breve à Alemanha e outros países.

24 A noção de "sentido" aqui proposta, entretanto, não é exatamente aquela de Caio Prado Jr., nem a do "sentido profundo" de Fernando Novais, como ficará claro adiante. Entretanto, ela guarda relações com essas duas noções. 
Essa idéia de progresso que surge com o capitalismo gerou e gera ainda vários equívocos. Nossa posição aqui pode ser pensada a partir da oitava tese de Walter Benjamin sobre o conceito de história:

"A tradição dos oprimidos nos ensina que o 'estado de exceção' no qual
vivemos é a regra. Precisamos chegar a um conceito de história que dê
conta disso. Então surgirá diante de nós nossa tarefa, a de instaurar
o real estado de exceçáo; e graças a isso, nossa posição na luta contra o
fascismo tornar-se-á melhor. A chance deste consiste, não por último, em
que seus adversários o afrontem em nome do progresso como se este fosse
uma norma histórica. O espanto em constatar que os acontecimentos
que vivemos 'ainda' sejam possíveis no século XX não é nenhum espanto
filosófico. Ele não está no início de um conhecimento, a menos que seja o
de mostrar que a representação da história donde provém aquele espanto
é insustentável."

Os equívocos das interpretações que vêem um "capitalismo ideal" ou uma "sociedade burguesa" ideal (com trabalho livre assalariado, democracia etc.), extraído de esquemas preconcebidos, nos parecem ser perfeitamente encaixados nesta crítica de Benjamin às concepções da história, que vêem no progresso uma norma histórica. O "estado de exceção" ${ }^{\text {25 }}$ trazido pelo capitalismo continua sendo a regra, particularmente para os países que nunca saíram da exceção, caso das ex-colônias. Esses países continuam até hoje esperando as promessas da modernidade, e a expressão econômica dessa espera foram os modelos de crescimento e desenvolvimento econômico em suas várias versões, que supunham que o subdesenvolvimento seria superado e todos seriam países ricos e democráticos um dia. Hoje parece ser claro, ao menos para as tradições críticas e não-dogmáticas de pensamento, que o subdesenvolvimento é um tipo de desenvolvimento capitalista, e não uma "etapa", e que a roda da história pode girar para trás com relação às conquistas que antes se tinha como certas, desde que isso seja necessário para a continuidade ou segurança da acumulação capitalista. ${ }^{26}$

25 O tema da exceção foi resgatado por Francisco de Oliveira em recente debate sobre a obra de Michael Löwy na Faculdade de Filosofia, Letras e Ciências Humanas da USP. Entendemos que em seu polêmico texto recente, O ornitorrinco, Oliveira mostra com maestria o monstrengo social que o capitalismo gerou no Brasil de hoje, com sua capacidade de gerar a exceção e colocar lado a lado o moderno e o atraso, que também são formas de manifestação da imensa desigualdade social neste País.

26 Basta atentar para o retrocesso nos direitos trabalhistas verificada nas três últimas décadas, mesmo nos países centrais, após o fim da Era de Ouro do capitalismo e do Welfare State, e para os freqüentes retrocessos nos direitos políticos que sofreram vários países ao longo do século XX (do fascismo, apontado por Benjamin, às ditaduras militares na América Latina), geralmente tendo a "segurança" como motivo. Para acontecimentos mais recentes, basta ver os retrocessos atuais, no plano das relaçốes internacionais e mesmo dos direitos individuais, vindos das nações que seriam as "guardiãs" da ética e da democracia burguesas, agora tendo como mote o "combate ao terrorismo". 
O curioso é que nos manuais de economia e nas teorias do desenvolvimento econômico, as condições dos países periféricos, subdesenvolvidos, ou "em desenvolvimento", são sempre vistas como exceções. Cabe aos países descobrirem quais são as características que os "desviam" do modelo ideal, para colocar-se nos trilhos do desenvolvimento (copiando padrões). E é interessante como na verdade o que nos modelos é a exceção, na realidade é a regra: o que é a "regra", para tais modelos, se aplica a pouco mais que uma dezena de países em todo o mundo. Benjamin aqui é atualíssimo.

Da mesma forma, e voltando ao nosso tema nesse artigo, o escravismo foi um desdobramento do capitalismo, a maneira como a forma capital surge na periferia do sistema e como ela incorporou as colônias na divisão internacional do trabalho. Não se trata, pois, a nosso ver, de "arcaísmo", como sugerem Fragoso e Florentino, ou de outro modo de produção, como sugere Gorender, mas simplesmente do estado de exceção como regra, trazido pelo próprio desenvolvimento contraditório e desigual do capitalismo.

Esta visão do capitalismo como um sistema mundial, e que se desenvolve de forma desigual e contraditória, tornando a exceção uma regra, não é nova, como já apontado. Ela está presente na concepção do papel do escravismo moderno em Fernando Henrique Cardoso, na noção de "idéias fora do lugar" de Roberto Schwarz, e também no papel do setor arcaico na acumulação do setor moderno em Francisco de Oliveira, na sua crítica à razão dualista.

O capitalismo prescinde da superestrutura burguesa, ${ }^{27}$ ou ao menos não precisa dela em todas as partes do mundo, sendo mesmo necessária, em alguns momentos, a sua ausência, para acelerar a acumulação. Em nossa visão, a forma capital, na busca da valorização infinita, é tão forte que, quando pode, prescinde das relações de produção capitalistas (caso do escravismo moderno e das formas de trabalho livre não-assalariado que existiram e ainda hoje existem no campo brasileiro). Ou pode prescindir, também, do conteúdo da valorização, que é a extração da mais-valia na esfera produtiva (caso do imenso circuito de valorização puramente financeira que reina hoje na

27 Penso aqui na análise que Fausto (1988, cap. 4) faz sobre o papel do Estado e da posição do Direito na sociedade capitalista, na visão marxiana. Segundo o autor, a posição do Estado e do Direito, ou seja, a posição da igualdade e da não contradição de classes no plano jurídico (com o trabalho livre e sua transformação em uma mercadoria como outra qualquer), que é a igualdade no plano da aparência do sistema, servem para esconder a desigualdade no plano da essência. Assim, aponta o autor que a contradição que Marx apresenta em $O$ capital, particularmente na passagem da seção I para a seção II, não é a contradição de classes, mas uma contradição entre a contradição de classes e a aparente ausência de contradição. $\mathrm{O}$ interessante para nossa discussão é que, na periferia do sistema capitalista, esta aparência por diversas vezes foi dispensada, ou seja, a acumulação capitalista aqui, baseada na exploração de classe, por diversas vezes prescindiu da máscara que precisou usar para prosseguir na Europa, seja utilizando-se do trabalho escravo, seja nas formas camponesas como a meação, formas nas quais fica clara a extração do excedente. 
economia mundial, cuja forma é D - D', ou seja, busca valorizar-se na esfera financeira sem passar pela produção).

É pelo fato de a forma capital ter tal força que ela pode prescindir, então, das características que constituiriam o "capitalismo ideal" - ideal tanto num sentido normativo como também no sentido de existir, ao menos em forma pura e generalizável a todo o globo, apenas no plano das idéias - reproduzindo constantemente o "estado de exceção", que assim se interverte em regra. O arcaísmo, neste sentido, não é précapitalista, não-capitalista ou anticapitalista, mas trazido pelo capitalismo em seu desenvolvimento contraditório. Como escreveu Marx nos Grundrisse (Marx, 1986), a principal característica que distingue o capitalismo dos modos de produção ${ }^{28}$ pré-capitalistas é o fato de que nestes a finalidade da produção é o valor de uso, ao passo que no primeiro a finalidade é a valorização do valor. As relações de produção são o meio para isso, mas uma vez que o movimento da forma ganha dinamismo, a finalidade é o mais importante, e o capital não faz questão de saber se o que gera o D’ ao final foi trabalho escravo, assalariado ou outra forma qualquer: o que importa é o resultado. Para o capital, os fins justificam os meios.

Tal força da forma capital também se desdobra em outra característica: o capital é o sujeito, e portanto não há um projeto das elites, seja ele modernizante ou arcaizante, mas o movimento de um sujeito automático, do qual os homens são meramente suportes, por meio das relações sociais de produção. Ou se pode dizer que desde o início o projeto de nossas elites, incluindo as mudanças de projeto com a mudança das elites hegemônicas, foi impulsionado pelo movimento do capital, ${ }^{29}$ movimento do qual as elites se alimentam e em função do qual atuam como classe. Se os resultados que isso trouxe para a periferia do sistema capitalista mundial foram diferentes dos casos "clássicos" de desenvolvimento capitalista, não se deve atribuir isso a uma anomalia, ou dizer que se tratou de um outro modo de produção, mas compreender

28 Na verdade, como destaca Fausto (1988, cap. 1), ao falarmos de sociedades passadas usando a expressão "modo de produção", como em "modo de produção feudal", o adjetivo "feudal" nega "modo de produção", pois só no capitalismo a produção torna-se a dimensão central das relações sociais, visto que a finalidade do sistema é a valorização do valor, que deve passar pela produção. Assim, o próprio conceito de modo de produção deve ser interpretado como um conceito afetado de negação ao usá-lo para se referir a sociedades pré-capitalistas.

29 Fragoso e Florentino, para reforçar seu argumento de que as açôes das elites mercantis do Rio de Janeiro eram primordialmente políticas e não econômicas, mostram que a rentabilidade das atividades rentistas para as quais se voltavam os comerciantes após enriquecerem (compra de imóveis, terras, escravos etc.) eram menos lucrativas que as atividades mercantis. Eles concluem com isso que o que eles buscavam era, portanto, status, poder, o que estaria de acordo com a idéia de um projeto arcaizante, não-capitalista. Uma objeção a se fazer é que, ainda que as taxas de rentabilidade nessas atividades de fato fossem menores, isto não habilita a concluir que eram ações não racionais ou não motivadas pela lógica da acumulação capitalista. Optar por um investimento menos rentável pode significar simplesmente aversão a risco. De qualquer forma, o consumo ostentatório, bem como a acumulação de riquezas pessoais e certos tipos de bens que trazem status não são de forma alguma estranhos a uma sociedade capitalista, como já mostrou Thorstein Veblen na sua famosa Teoria da classe ociosa. 
tais resultados como fruto do próprio desenvolvimento contraditório, desigual e excludente do capitalismo.

Uma última observação a ser feita, agora sobre a relação entre as classes dominantes domésticas (as elites) e sua relação com o movimento do capital no plano internacional. É curioso notar que as idéias de Fragoso e Florentino se aproximam das de Gorender neste aspecto, e ambas as concepções desembocam numa mesma linha de interpretação: a de que as mazelas dos países que foram ex-colônias são fruto de decisões equivocadas tomadas por eles mesmos (ou pelas suas elites, já que as classes populares nunca tiveram poder de decisão), e não resultado histórico da exploração ou da extração do excedente colonial, ou ainda do "imperialismo".

Gorender (1980, p. 65), após criticar a teoria da dependência e outras linhas interpretativas que destacam fatores externos como determinantes dos problemas nacionais, destaca que o foco dinâmico, em certos momentos cruciais, esteve na economia brasileira, nas atitudes das classes dominantes nacionais, e não apenas no "imperialismo" externo. De forma análoga, Fragoso e Florentino, como vimos, destacam o poder da elite nacional ante o capital mercantil europeu e o papel protagonista (ou antagonista) destas elites na reprodução de nosso "arcaísmo". Isto é um desenvolvimento lógico nos dois modelos pelo fato de destacarem a dinâmica interna da colônia, seja como modo de produção escravista colonial, seja como formação econômico-social. Perdese com isso, entretanto, a visão do capitalismo como um sistema mundial. É como se, na ânsia por combater as teses que enfatizavam a extração do excedente colonial - que tem seu ápice em Fernando Novais - os autores joguem fora o bebê com a água do banho, desprezando-se a posição da colônia no conjunto de um sistema mundial em formação.

Não queremos com isso defender interpretações fatalistas que retiram qualquer papel emancipador que possa surgir internamente ao País. Apenas acreditamos que foi exagerada a crença de que nossas elites poderiam ter mudado o rumo da história. E isto não se deu por mera "incompetência" dessas elites, mas pelas opções tomadas que envolviam as relações entre as elites internas e as elites do centro, ou entre o capitalismo nacional e o capitalismo mundial.

É por meio dessa relação que Fernando Henrique Cardoso, em sua versão da teoria da dependência, buscava (contra a esquerda embasada nas teorias do imperialismo) extrair os benefícios de um desenvolvimento "dependente e associado", apoiado politicamente na facção "esclarecida" da burguesia nacional, aquela mais atenta às oportunidades criadas pela internacionalização da economia e pela nova divisão internacional do trabalho que estava surgindo na década de 1960 com a expansão das multinacionais. Entretanto, sabemos bem o rumo a que essas idéias levaram quando ele teve sua 
oportunidade na presidência da República, já numa nova configuração do capitalismo mundial na qual a globalização financeira se tornou muito mais relevante que a produtiva, e a dependência anteriormente diagnosticada se transformou em uma dependência do mercado financeiro internacional que até hoje funciona como uma bola de ferro para o crescimento econômico brasileiro.

Acreditamos haver aqui uma lacuna ainda a ser preenchida, que é a de pensar o papel da periferia no sistema capitalista que não cometa o erro de atribuir todas as nossas mazelas ao "imperialismo" ou a fatores externos, nem tampouco cometa o erro oposto de atribuí-los puramente a "decisões equivocadas" das elites e dos governantes locais, ou à "corrupção", como se esta não existisse nos países centrais e não fizesse parte das regras do jogo capitalista. É preciso entender a relação entre as elites nacionais e os demais grupos sociais dentro dos países periféricos, as relações entre essas elites e as elites do centro, no movimento geral do capital no plano internacional, bem como a maneira como tais elites defendem seus interesses por meio de seus respectivos Estados Nacionais e organismos internacionais. Essas são, a nosso ver, as mediações fundamentais que devem ser investigadas para se compreender os diferentes períodos de nossa história.

Tais reflexões deverão também, conforme defendemos ao longo do texto, pensar no período colonial e no escravismo moderno não como um parêntesis, mas como a forma sob a qual o capitalismo se desenvolveu na periferia do sistema capitalista mundial, a forma como a inseriu na divisão internacional do trabalho, bem como na divisão internacional do poder. $\mathrm{O}$ "sentido da colonização", de nossa perspectiva, é esse: a criação da periferia de um sistema capitalista mundial. Não é um sentido teleológico, conforme já discutimos anteriormente, mas um sentido percebido "a posteriori”, e que tem à sua frente um sujeito histórico. Não um sujeito consciente, pois isto só viria, para Marx, com o fim da história - o socialismo - que na verdade seria o início da história com o homem surgindo como sujeito (ver Motta e Costa, 1995b). Mas um sujeito automático, que impede que o homem se torne sujeito: o capital.

Acreditamos que a partir dessa noção do "sentido da colonização" se poderá chegar a uma síntese, não só dos diversos modelos interpretativos de nossa formação, como também a uma síntese entre nosso passado e o presente, ou seja, iluminar o passado não apenas por erudição ou curiosidade intelectual, mas para que este lance luz sobre os problemas do presente. Esta, como escreveu Caio Prado Jr., é a principal tarefa de quem se debruça sobre nossa História. 


\section{REFERENCLAS}

Althusser, L.; Balibar, E. Para leer el capital. México: Siglo Veintiuno, 1978.

Cardoso, C. F. El modo de producción esclavista colonial en América. In: Assadourian, Carlos et alii, Modos de producción en América Latina. $3^{\mathrm{a}}$ ed. Buenos Aires: Cuadernos de Pasado y Presente, 40, p. 193-242, 1975.

Cardoso, C. F. et alii. Escravidão e abolição no Brasil: novas perspectivas. Rio de Janeiro: Jorge Zahar, 1988.

Cardoso, F. H. Capitalismo e escravidão no Brasil meridional. $5^{\text {a }}$ ed. Rio de Janeiro: Civilização Brasileira, 2004.

Cardoso, F. H.; Faletto, E. Dependência e desenvolvimento na América Latina: ensaio de interpretação sociológica. $3^{\mathrm{a}}$ ed. Rio de Janeiro: Zahar Editores, 1975.

Castro, A. B. A economia política, o capitalismo e a escravidão. In: Lapa, José R. do Amaral (org.), Modos de produção e realidade brasileira. Petrópoles: Vozes, 1980.

. Escravos e senhores nos engenhos do Brasil: um estudo sobre os trabalhos do açúcar e a política econômica dos senhores. Estudos Econômicos, v. 7, n. l, p. 177-220, jan./abr. 1977.

Ciafardini, H. Capital, comercio y capitalismo: a propósito del llamado "capita-lismo comercial. In: Assadourian, Carlos et alii, Modos de producción en América Latina. $3^{\mathrm{a}}$ ed. Buenos Aires: Cuadernos de Pasado y Presente, 40, p. 111-134, 1975.

Costa, I. del Nero da. Nota sobre a não existência de modos de produção coloniais. São Paulo: IPE/USP, 1985.

. Repensando o modelo interpretativo de Caio Prado Jr. Cadernos NEHD, São Paulo: FEA/USP, n. 3, 1995.

. Algumas opiniões sobre a categoria "modo de produção". Cadernos NEHD, São Paulo: FEA-USP, 1999.

Costa, I. del Nero da.; Pires, J. M. A fórmula do capital escravista-mercantil. Estudos Econômicos, v. 24, n. 3, p. 527-532, set/dez. 1994.

Fausto, R. Marx: lógica e política. Tomo I. $2^{\text {a }}$ ed. São Paulo: Brasiliense, 1987. . Marx: lógica e política. Tomo II. São Paulo: Brasiliense, 1988.

Fragoso, J. L. Homens de grossa-aventura: acumulação e hierarquia na praça mercantil do Rio de Janeiro (1790-1830). Rio de Janeiro: Civilização Brasileira, 1998.

Fragoso, J. L.; Florentino, M. O arcaísmo como projeto. $4^{\mathrm{a}}$ ed. Rio de Janeiro: Civilização Brasileira, 2001.

Furtado, C. [1959]. Formação econômica do Brasil. 17 ed. São Paulo: Nacional, 1980. 
Giannotti, J. A. Notas sobre a categoria 'Modo de Produção' para uso e abuso dos sociólogos. In: Estudos CEBRAP, n. 17. São Paulo: Ed. Brasileira de Ciências, 1976.

Gorender, J. O escravismo colonial. 4 ed. São Paulo: Ática, 1985.

. O conceito de modo de produção e a pesquisa histórica. In: Lapa, José R. do Amaral (org.), Modos de produção e realidade brasileira. Petrópoles: Vozes, 1980 .

Kuhn, T. S. A estrutura das revoluções científicas. São Paulo: Perspectiva, 1997.

Löwy, M. As aventuras de Karl Marx contra o Barão de Munchhausen: marxismo e positivismo na sociologia do conhecimento. São Paulo: Cortez Editora, 1996.

Marx, K. Elementos fundamentales para la crítica de la economía politica (Grundrisse). Madrid: Siglo Veintiuno, 1986.

. O capital: crítica da economia política. São Paulo: Abril Cultural, 1984. Coleção os Economistas, V. I, II e III.

. Formações econômicas pré-capitalistas. 3 ed. São Paulo: Paz e Terra, 1981.

. Para a crítica da economia política. (Prefácio). São Paulo: Abril Cultural, 1979. Coleção Os Pensadores.

Motta, J. F.; Costa, I. del Nero da. A formação econômica e social do Brasil sob nova ótica. Informações FIPE, n. 183, p. 18-22, dezembro 1995.

. O fim da história, o início da história. Informações FIPE, n. 172, p. 20-23, janeiro $1995 \mathrm{~b}$.

. Demografia histórica: da semeadura à colheita. Revista Brasileira de Estudos de População, Brasília, v. 14, n. 1/2, 1997.

Novais, F. Portugal e Brasil na crise do antigo sistema colonial (1777-1808). São Paulo: Hucitec, 1979.

Oliveira, F. Critica à razão dualista. São Paulo: Boitempo, 2003.

Pires, J. M.; Costa, I. del Nero da. O capital escravista-mercantil: caracterização teórica e condições históricas de sua superação. Revista Estudos Avançados, v. 14, n. 38, 2000.

Popper, K. R. A lógica da pesquisa cientifica. São Paulo: Cultrix, 1972.

Prado Júnior, C. Formação do Brasil contemporâneo: colônia. 17 ed. São Paulo: Brasiliense, 1981.

Schwarz, R. As idéias fora do lugar. In: Schwarz, R., Cultura e politica. São Paulo: Paz e Terra, 2001.

. Do lado da viravolta. In: Haddad, F. (org.), Desorganizando o consenso: nove entrevistas com intelectuais à esquerda. São Paulo: Fundação Perseu Abramo/ Vozes, 1998. Coleção Zero à Esquerda. 
Teixeira, R. A. Positivismo, historicismo e dialética na metodologia da economia. 2003. Dissertação (Mestrado), IPE/USP, São Paulo. (disponível em http://www.teses. usp.br). 